\title{
REPRESENTAÇÕES SOCIAIS DE ALUNOS DO ENSINO MÉDIO A RESPEITO DE MOSQUITOS (DIPTERA: CULICIDAE) E SUA RELAÇÃO COM PROBLEMAS AMBIENTAIS
}

\author{
Julio CESAR Rosa
}

Tese de Doutorado apresentada ao Departamento de Epidemiologia da Faculdade de Saúde Pública da Universidade de São Paulo para obtenção do Título de "Doutor em Saúde Pública."

Área de concentração: Epidemiologia

ORIENTADOR: Prof. DR. Delsio NATAL

São Paulo

2009

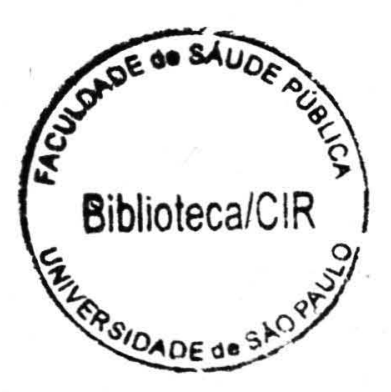


É expressamente proibida a comercialização deste documento, tanto na sua forma impressa como eletrônica. Sua reprodução total ou parcial é permitida exclusivamente para fins acadêmicos e científicos, desde que na reprodução figure a identificação do autor, título, instituição e ano da tese.

$$
50708 / 2009 \text { dxe }
$$


As Luas cheias riscam o céu de luzes e como crianças cadentes, sapecas, mágicas fogem desaparecem... na densa nebliná da noite nas lendas da madrugada nas brincadeiras encantadas

As Rosas claras encantam os corações apaixonados e como borboletas aladas fadas encantadas 1 fogem desaparecem... no jardim da cores nos gostos dos sabores nos contos de amores

três flores...

três fadas...

três amores...

À Clara Lua Rosa,

Amanda Lua Rosa,

e Alessandra Rosa. 
Aos meus Pais Julio e Carmen que sempre estimularam meus estudos,

mas não freqüentaram a escola no campo e

na cidade

Aos meus irmãos Carlos, Vera e Luciana que, cada um a sua maneira,

sempre contribuíram para minha caminhada segura.

Aos meus sobrinhos Arthur e Niara

que enriquecem com seus sorrisos nossa família.

A Guilherme

pelos caminhos e distâncias da vida. 
Ao Professor Delsio Natal

que me acompanhou e incentivou minha incursão na saúde pública,

pela confiança depositada e pela disponibilidade em orientar-me nesta pesquisa,

a minha homenagem e gratidão. 


\section{AGRADECIMENTOS}

Aos membros da Banca Examinadora Professores Fernando Lefèvre, Helena Ribeiro, Helene Mariko Ueno e José Luiz Laporta pela análise prévia da tese e pelas inestimáveis sugestões.

À Professora Ana Maria Cavalcanti Lefèvre pelo apoio, sugestões e amizade durante a realização deste trabalho.

À Pedagoga Sandra Santiago pelas entrevistas e transcrições realizadas.

À Professora Karim Roberta de Almeida pelas entrevistas realizadạ.

À Professora Cléa Regina Costa Lemos pelas entrevistas realizadás.

À Professora Sonia Cristina de Carvalho Moraes pelas entrevistas realizadas.

À Direção e Coordenação da EE. Parque Ecológico pela permissão e apoịo durante a realização deste trabalho.

À Direção e Coordenação da EE. Irmã Annete Marlene Fernandes de Mello pela permissão e apoio deste trabalho.

À Direção e Coordenação da EE. União de Vila Nova II pelo apoio deste trabalho.

Aos alunos das unidades escolares pela participação ativa no desenvolvimento deste trabalho.

À Professora A'lessandra Ferreira da Silva pelo estímulo, companheirismo e apoio em todos os momentos deste trabalho.

A todas as pessoas que nas mais diversas formas contribuíram com a realização desta pesquisa. 


\section{RESUMO}

Rosa, JC. Representações sociais de alunos do ensino médio a respeito de mosquitos (Diptera: Culicidae) e sua relação com problemas ambientais. São Paulo; 2009. [Tese de Doutorado - Faculdade de Saúde Pública da USP].

Objetivo: Identificar as representações sociais de alunos do ensino médio sobre mosquitos e sua relação com problemas ambientais. Método: $O$ universo da investigação foi composto por 194 alunos do ensino médio, das Escolas Estaduais, localizadas na área da Subprefeitura de Ermelino Matarazzo, no Município de São Paulo. A pesquisa foi feita por meio de entrevistas semi-estruturadas, por meio de gravações magnéticas e transcrição de fitas. $\mathrm{O}$ método empregado utilizou ùm conjùnto de instrumentos, as figuras metodológicas, que viabilizam discriminar os principais temas do discurso apresentado pelos alunos, no que se refere ao objeto de estudo. Os instrumentos em questão são a idéia central e o discurso do sujeito coletivo. Resultạdos: As 'representações sobre reprodução dos mosquitos demonstraram que houve fragmentação da aprendizagem em relação ao seu ciclo biológico e os aspectos ecológicos do mosquito, fato que pode comprometer as campanhas de controle desses vetores. Recomendações: Dialogar com os alunos sobre a necessidade de amplas medidas sanitárias ambientais para o controle dos vetores.

Descritores: insetos vetores, culicidae, educação em saúde, pesquisa qualitativa, ambiente e educação ambiental. 


\section{ABSTRACT}

Rosa, JC. Social representations of high school students about' mosquitoes (Diptera: Culicidae) and its relation to environmental problems. São Paulo, 2009. [Tese de Doutorado - School of Public Helath. USP].

Objective: To identify the social representations of students of high school on mosquitoes and their relation to environmental problems. Method: The research universe was composed of 194 high school students from state schools, located in the area of Subprefeitura of Ermelino Matarazzo, in São Paulo. The research was conducted through semi-structured by means of magnetic recording and transcription of tapes. The method employed used a set of instruments, the methodological figures, which make discriminating the main themes of the speech made by the students, regarding the object of study. The instruments in question are the central idea and discourse of the collective subject. Results: The breeding of mosquitoes on representations showed that there was fragmentation of learning in relation to their biological cycle and the ecological aspects of the mosquito, which may undermine the campaigns of control of vectors. Recommendations: Interact with the students on the need for extensive environmental health for the control of vectors.

Descriptors: insect vectors, culicidae, health education, qualitative research, environment and environmental educạtion. 


\section{Ápresentação}

No mestrado realizei pesquisa qualitativa com alunos do ensino fundamental que moravam em baịros̀ localizados no entorno Parque Ecológico do Tietể (utilizando-o para atividades de lazer, educação, esportes etc.) onde os sinais de problemas ambientais e proliferação de mosquitos eram evidentes, constituindo-se numa área vulnerável, sujeita ao risco de transmissão de agentes patogênicos por vetores biológicos apontando a necessidade de um trabalho educacional.

O ingresso em 2005 no doutorado da Faculdade de Saúde Pública da USP estimulou-me a aprofundar temática semelhante com o objetivo de identificar as representações sociais de alunos do ensino médio a respeito de mosquitos (diptera: culicidae).

A pesquisa ocorreu com alunos do ensino médio em duas unidades escolares que pertencem à subprefeitura de Ermelino Matarazzo, na cidade de São Paulo - SP. A região chamou-me a atenção em função dos alunos habitarem os bairros próximos ao Rio Tietê onde há intensa degradação ambiental e proliferação de mosquitos.

Nesta pesquisa foram utilizadas cinco perguntas. A coleta de dados ocorreu através de entrevistas semi-estruturadas gravadas em fitas magnéticas, posteriormente, transcritas respeitando as expressões verbais conforme emitidas.

As representações sociais sobre reprodução demonstraram que houve fragmentação da aprendizagem em relação ao ciclo biológico e os aspectos ecológicos do mosquito, fato que pode comprometer as campanhas de controle dos vetores. 
Esta pesquisa tem a finalidade de contribuir com a elaboração de programas de educação e saúde pública. 


\section{ÍNDICE}

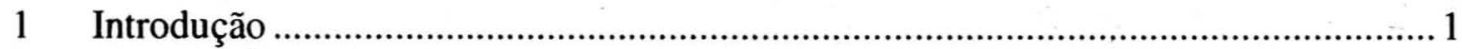

1.1 Educação Ambiental ............................................................................... 1

1.2 Desenvolvimento Sustentável x Sociedades Sustentáveis ................................... 6

1.3 Impactos Ambientais e Saúde.........................................................................

1.4 Culicídeos de Importância Epidemiológica. .................................................... 10

1.5 Participação Popular no Controle dos Vetores ................................................. 14

1.6 A Teoria das Representações Sociais ............................................................. 15

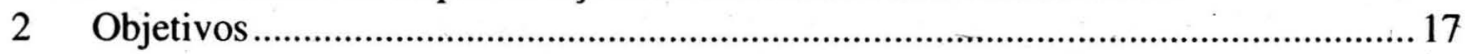

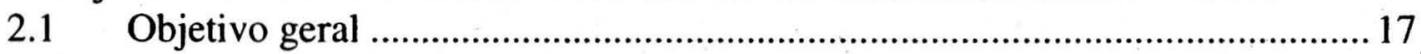

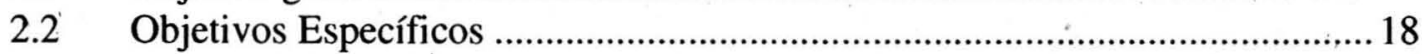

3 Sujeitos, Materiais e Métodos...……………………………………………..... 19

3.1 Caracterização da região de estudo............................................................ 19

3.2 População Alvo ....................................................................................... 20

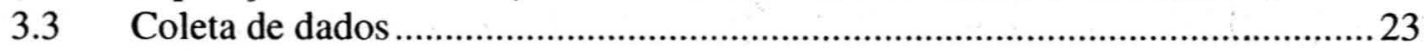

$3.4 \quad$ Análise dos dados ................................................................................... 25

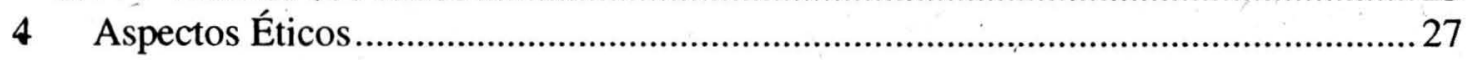

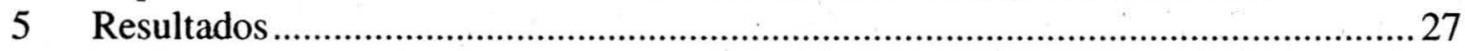

$5.1 \quad$ Caracterização da amostra pesquisada.........................................................2

5.2 Resultado Qualiquantitativos ..................................................................... 28

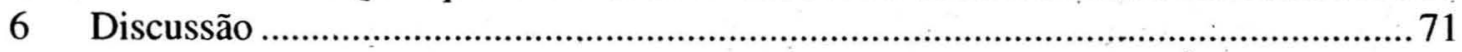

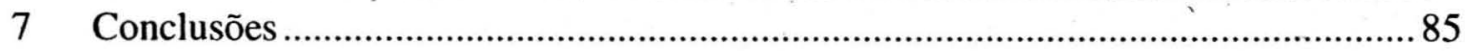

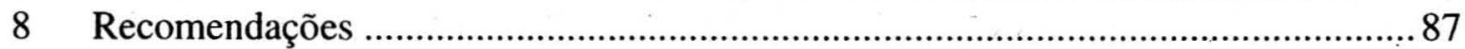

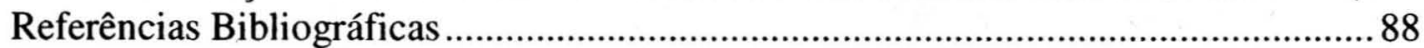

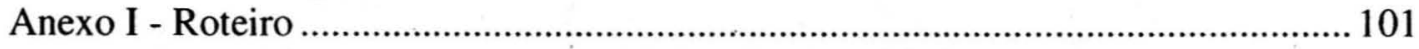

Anexo II - Termò de Consentimento Livre e Esclarecido ......................................... 102

Anexo III - Termo de Consentimento Livre e Esclarecido ............................................. 103

Anexo IV - Cálculo de Percentagem........................................................................... 104 


\section{Introdução}

\subsection{Educação Ambiental}

No ano de 1965, surgiu o termo Environmental Education (Educação Ambiental) durante a Conferência em Educação na Universidade de Keelle, Inglạterra. Nessa oportunidade, foi aceito que a educação ambiental deveria tornar-se parte fundamental da educação de todos os cidadãos (DIAS 2003).

Naquele mesmo ano, implantou-se o Conselho para Educação Ambiental, na Grã-Bretanha, para coordenar as organizações envolvidas com a educação e meio ambiente. Nos países nórdicos e na França foram elaboradas algumas deliberações ministeriais, parlamentares e de órgãos centrais do sistema educacional, estimulando a introdução da educação ambiental no currículo escolar (SORRENTINO 1995).

Em 1969, na Inglaterra, foi fundada a Sociedade de Educação Ambiental (Dias 2003).

Em 1972, o Clube de Roma, criado em 1968 por trinta especialistas de várias áreas, liderado pelo industrial Arillio Peccei publicou o seu relatório Os limites do crescimento, que denunciava o consumo e o crescimento exacerbado da sociedade, os quais levariam ao esgotamento dos recursoș naturais não renováveis, à poluição e escassez dos alimentos, indicando um limite de crescimento para a humanidade (DIAS 2003; PELICIONI 1998).

Em 1972, em Estocolmo, Suécia, a Organização das Nações Unidas, incitada pela repercussão internacional do Relatório do Clube de Roma, promoveu a I 
Conferência das Nações Unidas sobre o Meio Ambiente Humano ou Conferência de Estocolmo que reuniu representantes de 113 países com o objetivo de discutir os aspectos políticos, sociais e econômicos do meio ambiente global, para a preservação e melhoria do ambiente humano (DIAS 2003; MCCORMICK 1992; SORRENTINO 1995).

Em 1973, no Brasil a Presidência da República pressionada pelas instituições ambientalistas e pelo Banco Mundial, criou, no âmbito do Ministério do Interior, a Secretaria Especial do Meio Ambiente - Sema, responsável pela gestão integrada do ambiente (DIAS 2003).

Em 1975, em resposta às recomendações da Conferência de Estocolmo, a Organização das Nações Unidas para a Educação, a Ciência e a Cultura - UNESCO, promoveu em Belgrado, Iugoslávia, ò Encontro Internacional de Educação Ambiental, que contou com a participação de especialistas de 65 países, no qual foi lançado o Programa Internacional de Educação Ambiental - PIEA, coordenado pela UNESCO e PNUMA- Programa das Nações Unidas para o Meio Ambiente (DIAS 2003).

Ao final do encontro foi elaborada a Carta de Belgrado para confrontar as desigualdades sociais, econômicas e os impactos ambientais.

A Carta de Belgrado (Trechos):

Nossa geração tem assistido a um crescimento e progresso tecnológieo jamais observado, que trazem benefícios a muitas pessoas e ao mesmo tempo vêm càusando graves consequiências sociais e ambientais. A desigualdade entre ricos e pobres, entre as 
nações e dentro delas, vem crescendo; e existem evidências de uma crescente deterioração do ambiente físico, sob diferentes formas, em escala mundial. Embora causada principalmente por um número relativamente pequeno de nações, essa condição afeta toda a humanidade. (...) Os recursos do mundo devem ser desenvolvidos de modo a beneficiar toda a humanidade e proporcionar melhoria da qualidade de vida de todos. (...) A reforma dos processos e sistemas educacionais é decisiva para a elaboração desta nova ética de desenvolvimento e de ordem econômica mundial. Governos e formuladores de políticas podem ordenar mudanças e novas abordagens para o desenvolvimento, podem começar a melhorar as condições de convívio do mundo, mas tudo isso não passa de soluções de curto prazo, a menos que a juventude mundial receba um novo tipo de educação. Esta implicará um novo e produtivo relacionamento entre estudantes e professores, entre escolas e comunidades, e entre o sistema educacional e a sociedade em geral. (SMA 1994, p. 11).

A Primeira Conferência Intergovernamental sobre Educação Ambiental ocorreu em 1977, em Tbilisi, na Geórgia, organizada pela UNESCO e PNUMA, constituindo-se um marco na história da Educação Ambiental.

Em 1979, em San Jose, Costa Rica ocorreu o Seminário sobre Educação Ambiental para a América Latina, baseando-se nos encontros internacionais (DIAS 2003).

Em 1981, no Brasil, sob a luz da influência de Tbilisi foi promulgada a Lei Federal 6.938/81, que institui a Política Nacional do Meio Ambiente, suas finalidades e mecanismos de formulação e execução. Ela estabeleceu que a Educação deve ser oferecida em todos níveis de ensino (LEGISLAÇÃO DO MEIO AMBIENTE 1996). 
Em 1988, a Constituição Brasileira tornou obrigatória a inserção da Educação Ambiental em todos os níveis de ensino e a conscientização pública. Destaca-se o Artigo 225 do capítulo VI - Do Meio Ambiente:

“Todos têm direito ao meio ambiente ecologicamente equilibrado, bem de uso comum do povo e essencial à sadia qualidade de vida, impondo-se ao Poder Público e à coletividade o dever de defendê-lo e preservá-lo para as presentes e futuras gerações" E o capítulo IV - "Promover a educação ambiental em todos os níveis de ensino e a conscientização pública para a preservação do meio ambiente" (CONSTITUIÇÃO DA REPÚBICA FEDERATIVA DO BRASIL 1988).

Em 1992, realizou-se a Conferência das Nações Unidas sobre o Meio Ambiente e Desenvolvimento (Rio-92). Através do Capítulo IV, Seção IV da Agenda 21 a Rio-92 fortaleceu as recomendações de Tbilisi para a Educação Ambiental, dentre elas, está o entendimento da interdependência, social, política, econômica e ecológica dos aspectos ambientais, e a compreensão do meio ambiente em sua totalidade (DIAS 2003).

No mesmo ano, 1992, ocorreu o Fórum Internacional de Organizações Não Governamentais, ONGs e movimentos Sociais, importante para as reflexões ambientais (SANTOS 2001).

Em 1999, foi promulgada a Lei 9.795/99, no Brasil, que dispõe sobre a Educação Ambiental e dá outras providências.

O artigo terceiro da Lei, como parte do processo educativo mais amplo, todos têm direito à educação ambiental, incumbindo: 
1 - ao Poder Público, nos termos dos arts. 205 e 225 da Constituição Federal, definir políticas públicas que incorporem a dimensão ambiental, promover a educação ambiental em todos os níveis de ensino e o engajamento da sociedade na conservação, recuperação e melhoria do meio ambiente;

II - às instituições educativas, promover a educação ambiental de maneira integrada aos programas educacionais que desenvolvem;

III - aos órgãos integrantes do Sistema Nacional de Meio Ambiente Sisnama, promover ações de educação ambiental integradas aos programas de conservação, recuperação e melhoria do meio ambiente; IV - aos meios de comunicação de massa, colaborar de maneira ativa e permanente na disseminação de informações e práticas educativas sobre meio ambiente e incorporar a dimensão ambiental em sua programação; $\mathrm{V}$ - às empresas, entidades de classe, instituições públicas e privadas, promover programas destinados à capacitação dos trabalhadores, visando à melhoria e ao controle efetivo sobre o ambiente de trabalho, bem como sobre as repercussões do processo produtivo no meio ambiente;

VI - à sociedade como um todo, manter atenção permanente à formação de valores, atitudes e habilidades que propiciem a atuação individual e coletiva voltada para a prevenção, a identificação e a solução de problemas ambientais (MMA 1999).

A Educação Ambiental é um processo de ensino-aprendizagem para o exercício da cidadania; da responsabilidade social, econômica, política e ambiental. A ela cabe permitir a identificação e o entendimento dos problemas ambientais e suas possíveis soluções (PHILIPPI \& PELICIONI 2000). 


\subsection{Desenvolvimento Sustentável x Sociedades Sustentáveis}

A palavra desenvolvimento, entre outros significados, implica adiantamento, aumento, crescimento e progresso. Trata-se de estágio social, econômico e político de uma comunidade, caracterizado por altos índices dos fatores de produção, ou seja, os recursos naturais, o capital e o trabalho (FERREIRA 1998).

O conceito de desenvolvimento sustentável disseminou intensamente a partir de 1987 através do relatório da Comissão Mundial para o Meio Ambiente e Desenvolvimento conhecida como Comissão Brundtlạnd (NOSSO FUTURO COMUM, 1987), passando a ser usado nos documentos de órgãos de financiamento, por políticos, industriais e outros atores sociais. Esse conceito tem sido muito discutido e utilizado com propósitos diversos, inclusive, com o objetivo de ratificar posições, político ideológịcas que defendem os interesses capitalistas e de manutenção da situação sócioeconômica cultural vigente, que fomenta as desigualdades sociais (DIEGUES 1992).

Para Herculano (1992, p.30) “o termo ‘desenvolvimento' prende o debate ao campo restrito da economia é reafirma sua hegemonia num momento em que o mais importante é reduzi-la àquilo que ela tão-somente é, um mero instrumental, que deve estar subordinado às questões éticas mais substantivas".

Os conceitos de desenvolvimento se baseiam na necessidade de atingir o ápice de "desenvolvimento" obtido pelos países industrializados. O estilo de desenvolvimento dessas sociedades, fundamentado num consumo exacerbado de recursos naturais, principalmente aqueles provenientes dos países do Terceiro Mundo, é insustentável em médio e longo prazo (PELICIONI 2002). 
De acordo com MINAYO (1998, p. 4) o conceito de:

\begin{abstract}
Desenvolvimento sustentável deixou de ser a palavra mágica que durante quase meio século (a partir da 2a Guerra Mundial) embalou os planos dos países desenvolvidos e os sonhos dos subdesenvolvidos, numa visão evolucionista do progresso, numa corrida de domínio sem limites da natureza e das matérias primas, de forma desenfreada, predatória e anárquica. Hoje a palavra desenvolvimento parece inspirar mais problemas que soluções, num mundo que conseguiu globalizar fómes, continentais, conflitos étnicos, comprometimento de qualidade de vida, poluição, desemprego crescente e estrutural, violência, drogas, esgotamento de recursos naturais, ameaças a extinção de espécies e desastres ecológicos.
\end{abstract}

Há uma corrente teórica que preconiza o Tratado de Educação Ambiental para Sociedades Sustentáveis e Responsabilidade Global, elaborado durante encontro internacional, na cidade do Rio de Janeiro em 1992 (SATO 2002).

Segundo Rodrigues (1996), uma sociedade sustentável pode ser definida como a que vive e se desenvolve integrada à natureza, considerando-a um bem comum, respeitando à diversidade biológica e sociocultural. O desenvolvimento deve ser centrado no exercício responsável e conseqüente da cidadania, o que demandaria distribuição eqüitativa das riquezas produzidas.

Diegues (1992, p. 28) comenta que:

O conceito de "sociedades sustentáveis" parece ser mais adequado que o de "desenvolvimento sustentável" na medida em que possibilita a cada uma delas definir seus padrões de produção e consumo, bem como o de bem-estar a partir de sua cultura, 
de seu desenvolvimento histórico e dè seu ambiente natural. Além disso, deixa-se de lado o padrão das sociedades industrializadas, enfátizando-se a possibilidade da existência de uma diversidade de sociedades sustentáveis, desde que pautadas pelos princípios básicos da sustentabilidade ecológica, econômica, social e política. (...) Essa noção de sociedades sustentáveis se baseia na noção expressa por Chambers na qual as pessoas, sobretudo as mais pobres, devem ser sujeitos e não objetos do "desenvolvimento". O meio ambiente e o desenvolvimento, para esse autor, são meios e não fins em si mesmos. Nesse sentido ele se refere à sustentabilidade dos modos de vida, onde a qualidade de vida passa a ser uma prioridade.

Os recursos necessários a manutenção da vida devem ser utilizados de acordo com a capacidade natural de renovação dos ecossistemas, o que promoveria processo favorável à garantia de condições apropriadas de vida para as gerações atuais e futuras.

\subsection{Impactos Ambientais e Saúde.}

O modelo socioeconômico predatório de desenvolvimento da humanidade é insustentável e consome intensamente os recursos naturais necessários à manutenção da vida no planeta. O crescimento rápido e desordenado das cidades provoca déficits ainda insuperáveis no saneamento, na educação e na saúde, contribuindo dessa forma, para a proliferação de algumas espécies de mosquitọ com importância epidemiológica (LAPORTA e col. 2006).

Parcela significativa da população vive na miséria, proveniente da zona rural migrou para grandes cidades buscando melhoria da qualidade de vida, mas na maioria das vezes, continuam sem emprego, escolas, hospitais, saneamento, entre outros serviços básicos (LENZI e col. 2000; PEREIRA 2001; FREITAS e col. 2002). Em virtude da 
omissão do poder público, a população pode descartar o lixo nas ruas e córregos, bem como estocarem água, práticas que favorecem a proliferação de vetores e outros animais sinantrópicos. Parte desta população passou a viver em cortiços e favelas. Estima-se que cerca de $22 \%$ da população de grandes cidades da América Latina estejam nestas condições (TAUIL 2001).

Décadas de urbanização e industrialização não planejados em São Paulo transformaram os rios em esgotos a céu aberto. Devido à ausência de uma política de saneamento básico eficiente, suas margens tornaram-se, muitas vezes, moradia de populações excluídas (BRACCO 1998), expostas a diversos agravos à saúde.

A degradação dos rios e reservatórios para o abastecimento de água das metrópoles é consequiência do processo de industrialização e crescimento populacional (BORGES 1998). Especialistas em entomologia urbana pesquisam as inter-relações entre a urbanização e a consequiente interferência na composição e estrutura das populações de insetos vetores de doenças (COOSEMANS \& MOUCHET 1990).

BRACCO (1998) comenta:

A questão da melhoria da qualidade de vida das populações que moram ou não nas margens de rios e córregos da cidade de São Paulo, inclusive no que diz respeito ao incômodo causado pela presença de mosquitos em altas densidades, passa necessariamente pela retomada, pela re-apropriação desses mesmos rios e córregos, como uma regiãơ de lazer e bem estar social. Investimentos em uma rede de coleta e tratamento de esgotos clandestinos, programas de tratamento dos resíduos industriais lançados nos rios, urbanização de favelas transformação das margens dos grandes rios (Tietê e Pinheiros) em áreas verdes de lazer para a população, seriam a melhor 
forma de resgatar os rios paulistanos, reintegrando-os como parte viva da cidade (p. 101).

O rio Tietê na cidade de São Paulo transformou-se em abrigo e criadouro de inúmeros animais sinantrópicos, dentre eles, algumas espécies de mosquitos.

Criadouros podem ser classificados como naturais ou artificiais. Os naturais buracos em pedra, buracos no chão, bromélias, ocos de árvores, làgos, etc. - não sofrem interferência direta do homem (O’MERA 1993,1997; YADAV e col 1997; FORATTINI e col. 1998). Os criadouros artificiais são, produzidos pelo homem. Muitas embalagens descartáveis são lançadas ao ambiente, provocando inúmeros problemas ambientais e freqüentemente transformando-se em criadouros de mosquitos.

Os recipientes presentes nos terrenos baldịos e nas residências estão associados a um aumento do risco de transmissão do vírus do dengue (OPS 1991). Segundo GUBLER (1989), há inúmeros recipientes artificiais que se tornaram habitats ideais para larvas de mosquitos.

\subsection{Culicídeos de Importância Epidemiológica}

Mosquitos do gênero Culex, subgênero Culex, parecem beneficiar-se de modificações no ambiente feitas pelo homem. Freqüentemente, observa-se sua colonização em ecossistemas naturais e artificiais resultante da ação humana (GOMES \& FORATTINI 1990). A manutenção da transmissão de filariose em uma região é um 
indicador de degradação ambiental e está associada à elevada densidade populacional do vetor (REGIS e col. 1996).

As formas imaturas de Culex quinquefasciatus não somente pode se desenvolver em águas limpas, como se proliferam em diversos criadouros, principalmente, em valas, córregos, canais, rios, recipientes com água estagnada, ricà em matéria orgânica em decomposição, corpos d'água repletos de poluentes e detritos de aspecto sujo e mal cheirosos (GOMES \& FORATTINI 1990; SEGHAL \& PILLAI 1970; TAIPE-LAGOS \& NATAL 2003; URBINATTI e col. 2001).

As fêmeas de Culex quinquefasciatus têm tendência à alimentação com sangue humano (CONSOLI \& LOURENÇO-DE-OLIVEIRA 1994), o que permite seu desenvolvimento nas cidades, sendo, portanto um importante vetor de inúmeros agentes patogênicos ao homem (FORATTINI 2002) e provocador de intenso incômodo para as populações que vivem próximas aos seus criadouros (NATAL e col. 1991; ROSA 2004; TAIPE-LAGOS \& NATAL 2003). Pesquisas inferiram que essa espécie apresenta índices elevados de domiciliação (FORATTINI e col. 1973; NATAL e col. 1991) é de sinantropia (FORATTINI e col. 1993; NATAL e col. 1995). Segundo CONSOLI \& LOURENÇO-DE-OLIVEIRA 1994, essa espécie é a principal transmissora da filariose em alguns Estados do país. Tal capacidade decorre do seu comportamento de hábitos noturnos e elevada antropofilia (FORATTINI 1965).

Há parasitoses que provocam muitos problemas de ordem física, enquanto outras, além desses problemas podem também causar danos de dimensão social, como por exemplo; a filariose linfática bancroftiana. Os doentes podem sofrer segregação social, em função das deformidades no corpo (braços, pernas, escroto, vulva e mama), às vezes 
irreversíveis em estágio avançado. Esta doença está associada a diversos fatores, entre eles, a miséria, ausência saneamento do meio, desinformação, desorganização e favelização (FUNASA 2000). O estigma social e a debilidade física associados à filariose linfática têm sido considerados como a segunda causa mundial de incapacidade para o trabalho (WHO 1995), atinge cerca de 100 milhões de pessoas no mundo, sendo prevalente em 83 países de climas tropical e subtropical (WHO 2005).

Na proposta da Organização Mundial de Saúde, a filariose linfática está incluída como uma das seis doenças infecciosas erradicáveis ou potencialmente erradicáveis (CDC 1993; WHO 1994), baseando-se nesta proposta o ministério da saúde, em 1996, definiu novas diretrizes de ação com o Plano de Eliminação Nacional da Filariose Linfática, que teve como parâmetro a descentralização das ações de controle.

Motta e Teixeira (2007) cometam que:

\begin{abstract}
Vale ressaltar que a filariose pode ser controlada/combatida efetivamente por meio de ações preventivas simples, como: diminuição do contato homem-muriçoca, mediante a eliminaçāo de focos de muriçoca peridomiciliares, uso de mosquiteiro; melhoria das condições ambientais, com a ampliação do serviço de esgotamento sanitário, cuidados com o destino do lixo; higiene pessoal dos portadores da doença, diminuindo, assim, a , recorrência de crises de erisipela, que potencializam as chances de estabelecimento da elefantíase (p. 324).
\end{abstract}

Mattos e col. (2008) citam que,

As condições subumanas de moradia da população atingida pelo agravo agem como um forte co-fator social, trazendo à baila a dissociação entre o poder decisório das políticas públicas e as evidências científicas. $O$ parasita tira vantagens das condições do subdesenvolvimento e vem como mais um agravo para a população, já tão fragilizada 
pela falta de controle social na política de saúde pública do Brasil. A adoção de práticas estatizadas, como o saneamento, não mais necessita de argumentos de defesa. Especificamente em relação à filariose, esse seria o caminho mais curto e definitivo, já que o vetor melhor se reproduz em águas contaminadas por excretas humanas. A prevenção é essencialmente um ato político; penetra nas teias dos poderes constituídos pela sociedade e deveria ser articulada com a sociedade civil organizada para responder, com alternativas de solução, às necessidades dessa parcela de cidadãos alijados dos seus direitos de viver com dignidade (p. 34).

Parcela significativa da população paulistana que habita o entorno do Rio Tietê sofre com a presença de diversas espécies de animais sinantrópicos, entre eles, os mosquitos do gênero Culex. O precário controle na região da população de Culex quinquefasciatus devido à ausência de saneamento ambiental por omissão do poder público, obriga os moradores ao uso de inseticidas.

Othmar Zeidler em 1874, sintetizou o DDT (Dicloro-Difenil-Tricloroetano), sua ação inseticida foi descoberta em 1939 (PANPANA 1963), fato que promoveu enormes perspectivas para o controle de doenças transmitidas por vetores, como dengue, filariose, febre amarela, leishmaniose, malária, entre outras (BRACCO 1998).

O uso generalizado se deu por Paul Muller na década de 40 durante a Segunda Guerra Mundial nas frentes de batalha, contra pulgas dos ratos, piolhos humanos e mosquitos (WHO 1987; ROZENDAAL 1997).

A metodologia não deve ficar restrita ao controle químico e/ou biológico, uma vez que, as interações ecológicas entre a espécie e seu habitat são complexas (VÍTOR NETO 2006). 
Em uma população de vetores expostos a inseticidas, sobrevivem os naturalmente resistentes, que transferem seu DNA a seus descendentes; outra maneira de sobrevivência é a comportamental, que seleciona mosquitos com aptidão para evitar total ou parcialmente o contato com o inseticida (OMS 1986).

\subsection{Participação Popular no Controle dos Vetores}

Novas abordagens sobre o controle de vetores devem ser elaboradas, como o desenvolvimento de medidas de controle comunitárias baseadas na organização e nos conhecimentos regionais da população (KENDALL e col. 1991).

A pesquisa científica na sua relação com os movimentos sociaís pode e deve se colocar como integrante de uma ampla rede de convivência, buscando o fortalecimento e ampliação das redes sociais de apoio no controle dos processos endêmico-epidêmicos (OLIVEIRA 1998).

A participação da população e a Educação em Saúde devem ser componentes primordiais de todos os programas de controle de enfermidades transmitidas por vetores (OPS 1991).

A escola é um espaço fundamental para envolver a população na busca de soluções para diversos problemas locais, entre eles, o controle de mosquitos; geralmente, os alunos são da própria comunidade, representando a maioria das famílias, tendo mais facilidade para entender os temas abordados, podendo mudar mais facilmente as atitudes negativas em relação ao controle de mosquitos (ROSA 2004). 
Os alunos precisam perceber os conteúdos ensinados como instrumentos de reflexão. A escola necessita dar esta oportunidade, bem como estimulá-los a résolverem problemas e conflitos reais coletivamente, e a participarem ativamente das discussões. Desta forma a escola assume um trabalho pedagógico transformador, que poderá refletir na qualidade de vida dos seus alunos (MEC 1998).

\subsection{A Teoria das Representações Sociais}

Moscovici (1978) elaborou trabalhos consideráveis, importantes para psicologia, história e ciências sociais. A Teoria das Representações Sociais originou-se na Europa, com a publicação do estudo La Psychanalyse: Son image et son Public. Sua Teoria têm influenciado pesquisadores em diversos países, inclusive no Brasil (Oliveira 2004), oferecendo suporte para a produção de coṇhecimento sobre os indivíduos enquanto portadores de sentimentos, crenças e idéias comuns ao universo cultural de um grupo. Suas raízes podem ser observadas no conceito de representações coletivas de Durkheim, que estudava fenômenos próprios de sociedades tradicionais.

De acordo com Durkheim (citado por MINAYO 1995):

as rèpresentações coletivas traduzem a maneira como o grupo se pensa nas suas relações com os objetos que o afetam. Para compreender como a sociedade se representa a si própria a ao mundo que a rodeia, precisamos considerar a natureza da sociedade e não a dos indivíduos. Os símbolos com que ela se pensa mudam de 
acordo com sua natureza (...). Se ela aceita ou condena certos modos de conduta, é porque entram em choque ou não com algum dos seus sentimentos fundamentais, sentimentos estes que pertencem à sua constituição (p.90-1).

Moscovici iniciou sua teoria com estudo das representaçõ̀es sociais de um fenômeno moderno, inserido no universo científico, a Psicanálise (FARR 1995). Segundo o mesmo "o papel que a teoria das representações sociais confere à racionalidade da crença coletiva e sua significação, portanto, às ideologias, aos saberes populares e ao senso comum". Tais representações são tomadas imediatamente como sistemas coerentes de signos, ou então, tratadaș como imagens, vizinhas de uma práxis e de um ritual, que têm existência de modo independente (MOSCOVICI 1995).

Para Minayo (2000) o estudo das representações sociais pode ser abordado através da pesquisa qualitativa, capaz de incorporar a questão do significado e da intencionalidade como inerentes aos atos, às relações e às estruturas sociais, tomadas como construções humanas significativas. Os conflitos, idéias, crenças, comportamentos presentes no campo social são expressados através da comunicação verbal.

Abric (1998) define a representação como "uma visão funcional do mundo, que, por sua vez, permite ao indivíduo ou ao grupo dar um sentimento às suas condutas e compreender a realidade através de seu próprio sistema de referências; permitindo assim ao indivíduo se adaptar e encontrar um lugar nesta realidade" (p.27-8).

O contato do pesquisador com as representações sociais de um grupo costuma se dar através da fala individual de uma ou mais pessoas tomadas como representativas do pensamento de grupo ao qual tais indivíduos pertencem. 
Segundo Michelat (1985) "cada indivíduo é portador de cultura ou das subculturas.às quais pertencem e é representativo delas" (p.194). Ele considera a constituição das culturas como resultados de processos históricos, nos quais a produção ideológica das diferentes estruturas sociais é interiorizada pelo indivíduo de maneira que as produções verbais dos mesmos podem fornecer informações sintomáticas sobre o modelo de sua cultura.

Para Wagner (1998), o processo constitutivo das representações sociais se dá, geralmente, através de mudancas ocorridas na sociedade:

(...) Muito frequientemente, será uma mudança nas condições de vida dentro da sociedade que dá surgimento a uma reelaboração e modificação da concepção dos objetos sociais. Até esse ponto, um fenômeno desconhecido e portanto não familiar, resultante das mudanças nas condições de vida de um grupo, se suficiente relevante, inicia um processo de comunicação coletiva para torná-lo inteligível e controlado (p. 10-1).

\section{Objetivos}

\subsection{Objetivo geral}

- Identificar as representações sociais de alunos do ensino médio a respeito. de mosquitos (diptera: culicidae). 


\subsection{Objetivos Específicos}

1. Identificar representações sociais dos alunos a respeito da reprodução de mosquitos.

2. Identificar representações sociais dos alunos a respeito de problemas provocados por mosquitos.

3. Identificar representações sociais dos alunos sobre controle de mosquitos.

4. Identificar representações sociais dos alunos a respeito da espécie de mosquito mais comum na residência.

5. Verificar se os alunos estabelecem relação entre problemas ambientais locais e proliferação de mosquitos.

6. Caracterizar o grupo pesquisado quanto ao local de moradia, sexo, idade e série a que pertence. 


\section{Sujeitos, Materiais e Métodos}

\subsection{Caracterização da região de estudo}

A pesquisa ocorreu com alunos do ensino médio em duas unidades escolares da subprefeitura de Ermelino Matarazzo do município de São Paulo: Escola Estadual (EE). Irmã Annete Marlene Fernandes de Mello, localizada na Rua Arlindo Betio, No 45 B, no Jardim Keralux e Escola Estadual (EE) Parque Ecológico, localizada na Rua Japichauá, s/n, no bairro de Ermelino Matarazzo. Ambas possuem ensino fundamental e o ensino médio, funcionando nos períodos da manhã, tarde e noite. A Subprefeitura de Ermelino Matarazzo abrange os distritos de Ermelino Matarazzo e Ponte Rasa. O primeiro apresentava em 2000 uma população de 105.202 pessoas e o segundo de 98.490 pessoas, vale destacar o percentual de crescimento da área de 1996 a 2000 que apresentou no. distrito de Ermelino Matarazzo 1,45\% e-no da Ponte Rasa -0,92\%. A Subprefeitura tem uma área total de $15,10 \mathrm{~km}^{2}$, sendo que $8,7 \mathrm{~km}^{2}$ pertencente ao distrito de E. Matarązzo e $6,4 \mathrm{~km}^{2}$ ao distrito da Ponte Rasa. A densidade demográfica na Subprefeitura no total de $13.531 \mathrm{Hab} / \mathrm{km}^{2}$. No distrito de Ermelino Matarazzo a densidade é de 12.268 e. no da Ponte Rasa, de $15.248 \mathrm{Hab} / \mathrm{km}^{2}$ (PMSP 2008a).

A população da área apresenta o seguinte grau de escolaridade: 57.722 habitantes possuem ensino fundamental completo; 45.308 habitantes possuem ensino médio completo; 9.083 habitantes possuem ensino superior completo (PMSP 2008b). 


\subsection{População Alvo}

O universo de investigação foi composto por uma amostra de 194 alunos do ensino médio regular e alunos da educação para jovens e adúltos (EJA) do ensino médio das Escolas Estaduais (EE) localizadas na região da Subprefeitura de Ermelino Matarazzo: EE Irmã Annete Marlene F. de Mello com onze classes: $\left(1^{\circ} \mathrm{A}, 1^{\circ} \mathrm{B}, 1^{\circ} \mathrm{C}, 1^{\circ}\right.$ EJA-A, $2^{\circ}$ A, $2^{\circ}$ B, $2^{\circ}$ EJA-A, $3^{\circ}$ A, $3^{\circ}$ B, $3^{\circ}$ EJA-A e $3^{\circ}$ EJA-B); EE. Parque Ecológico com oito classes: $\left(1^{\circ} \mathrm{A}, 1^{\circ} \mathrm{B}, 1^{\circ} \mathrm{EJA}-\mathrm{A}, 1^{\circ} \mathrm{EJA}-\mathrm{B}, 2^{\circ} \mathrm{A}, 2^{\circ}\right.$ EJA-A, $3^{\circ}$ A e $3^{\circ}$ EJA-A). Cada classe possuía em média 40 alunos.

Diante da dificuldade de se entrevistar 760 alunos (440 da EE. Irmã Annete e 320 EE. Parque Ecológico) devido ao tempo exíguo e diante da possibilidade de se utilizar um procedimento de amostragem, foi elaborada uma amostra com partilha proporcional constituída por cerca de 1/4 do universo, aproximadamente 194 alunos. Este número garante, com probabilidade de $95 \%$, que o erro máximo da estimativa de proporções seja de 10\% (DIXON 1957).

Cada aluno do universo de investigação constitui-se uma unidade amostral. Cada classe foi considerada, para fins de sorteio da amostra, como um estrato. Dentro de cada estrato procedeu-se ao sorteio das unidades amostrais, na proporção mencionada, na caixa com os nomes dos alunos. A amostra é, portanto, aleatória, estratificada por partilha-proporcional. 
O critério de escolha das unidades escolares, deveu-se aos seguintes fatores: os alunos das escolas habitam os bairros próximos ao Rio Tietê onde os sinais de problemas ambientais̀ e proliferação de mosquitos são evidentes (Figura 1 e Figura 2), apontando a necessidade de um trabalho educacional que envolva a comunidade.

Pesquisa realizada por Rosa (2004) demonstrou que os alunos do ensino fundamental da região têm pouco grau de conhecimento sobre os seguintes fatores: espécies de culicídeos do local, controle de mosquitos, problemas ambientais e proliferação de mosquitos, doenças transmitidas por mosquitos, bem como dos principais criadouros de Culex quinquefasciatus na região. 


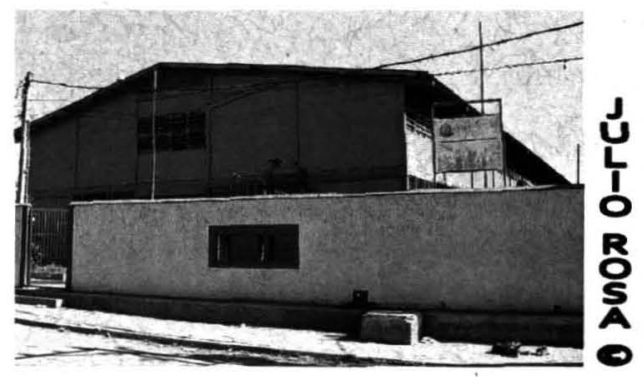

A. EE. Parque Ecológico.

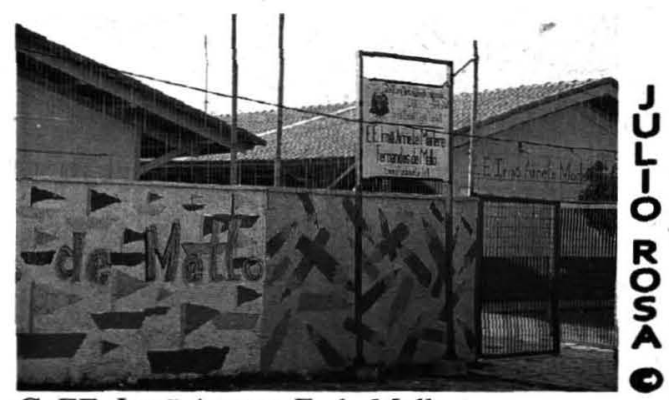

C. EE. Irmã Annete F. de Mello

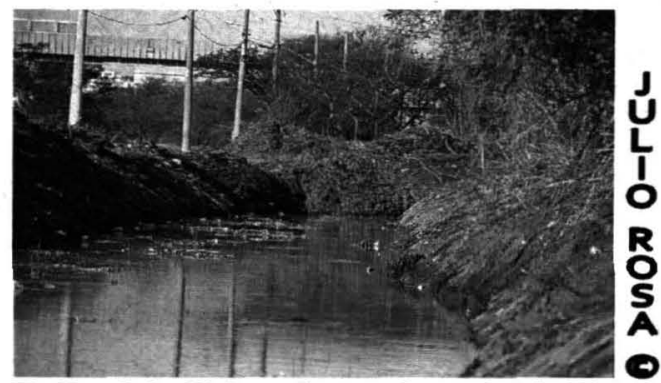

E. Canal de Cirçunvalação, denominado Rio "Negrinho", Próximo à EE. Irmã Annete.

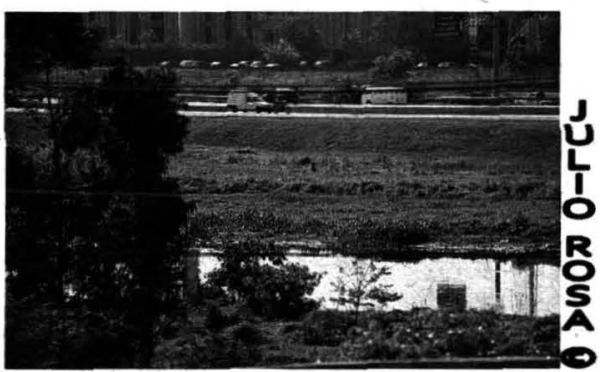

B. Rio Tietê em frente à EE. Parque Eco lógico.

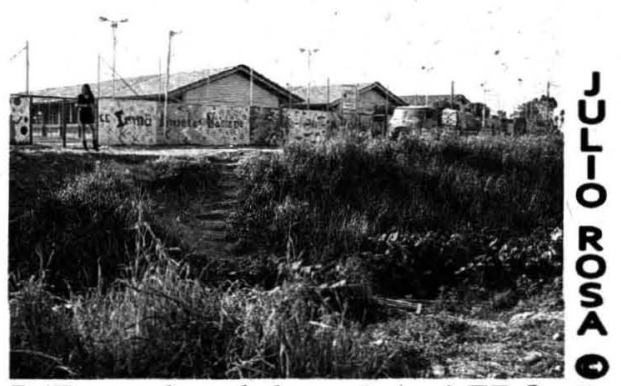

D. Esgoto degradado em frente à EE. Irmã Annete.

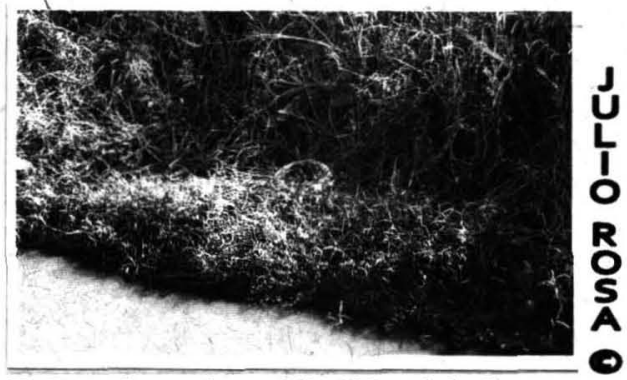

F. Pneu lançado no Rio "Negrinho".

Figura 1. Unidades escolares inseridas na área da subprefeitura de Ermelino Matarazzo: A, B, C, D, E e F. 


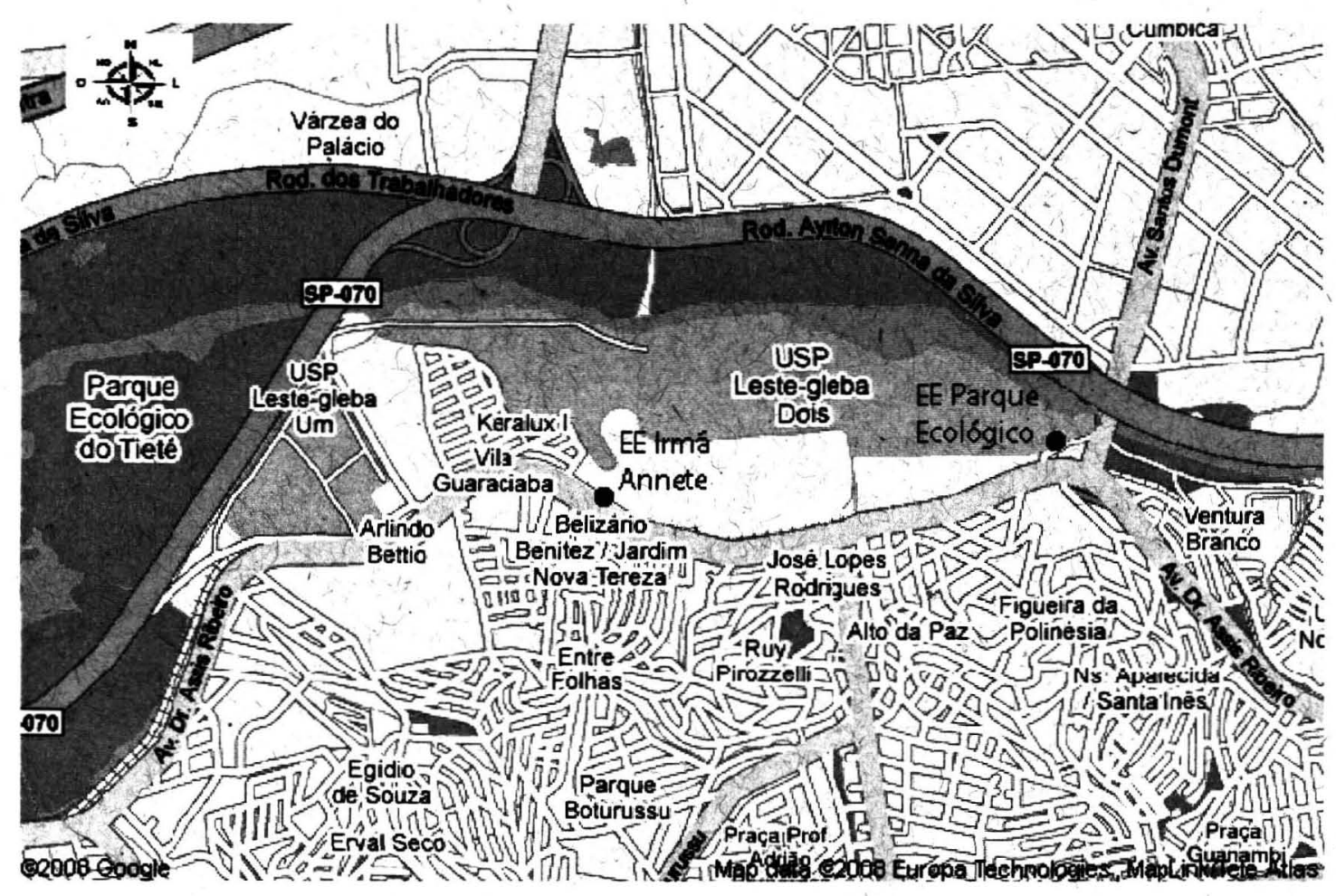

Figura 2. Mapa da área de pesquisa com a localização das Escolas: EE. Parque Ecológico e EE. Irmã Annete (GOOGLE 2008).

\subsection{Coleta de dados}

Na primeira visita as escolas foi explicado o objetivo da pesquisa, a importância da colaboração do aluno, a garantia do anonimato, a não obrigatoriedade da participação e sua importância para contribuir com a elaboração de programas de educação e saúde pública. 
Trata-se de estudo transversal. As entrevistas foram feitas nas unidades escolares nos dias: 15 de maio de 2007 (EE. Parque Ecológico) e 23 de maio de 2007 (EE. Irmã Annete) em ambientes sem interferềncias, favorecedores da privacidade e do sigilo das informações. Ocorreram individualmente em quatro classes diferentes antes do intervalo das aulas para evitar a troca de informações entre os alunos, onde buscou-se as representações sociais de cada individuo sobre mosquitos. $\bar{A}$ coleta de dados foi supervisionada pelo próprio pesquisador, com o auxilio de quatro profissionais devidamente orientados para assegurar uniformidade, através de entrevistas semiestruturadas gravadas em fitas magnéticas.

Segundo Simioni e col. (1997, p.6) "por entrevistas abertas semi-estruturadas devemos entender aquelas em que o informante fala livremente sobre o tema proposto, limitando, contudo, por um roteiro de questões a serem pontuadas no momento da entrevista."

Para Gil (1991), podemós "definir entrevista como a técnica em que o investigador se apresenta ao investigado e lhe formula perguntas, com o objetivo de obtenção de dados que interessam à investigação. A entrevista é, portanto, uma forma de interação social. Mais especificamente, é uma forma de diálogo assimétrico; em que uma das partes busca coletar dados e a outra se apresenta como fonte de informação."

As transcrições das entrevistas foram efetuadas, respeitando as expressões verbais conforme emitidas.

Foram elaboradas cinco questões abertas (Anexo I), testadas pelo próprio pesquisador que entrevistou 12 alunos do ensino médio, sendo quatro alunos de cada série $\left(1^{\circ}, 2^{\circ}\right.$ e $\left.3^{\circ}\right)$ na Escola Estadual E.E. União de Vila Nova II, localizada na Rua 
Delta, $\mathrm{s} / \mathrm{n}^{\circ}$ no Jardim Jacui, município de São Paulo. Esta unidade possui uma população escolar com características semelhantes as das unidades pesquisadas, a fim de serem encontrados possíveis erros de interpretação referentes às questões apresentadas podendo, assim, aperfeiçoar as mesmas, assegurando confiança e validade aos dados obtidos na pesquisa.

$\mathrm{O}$ resultado do pré-teste demonstrou que os alunos compreenderam as questões propostas, com exceção da quarta que foi então modificada para atingir o objetivo da pesquisa.

\subsection{Análise dos dados}

O estudo das representações sociais pode ser ạbordado através da pesquisa qualitativa, capaz de incorporar a questão do significado e da intencionalidade como inerentes aos atos, às relações e às estruturas sociais, tomadas como construções humanas significativas. As idéias, as crenças, os conflitos e os comportamentos presentes no campo social são expressos através da comunicação verbal (MINAYO 2000).

O método empregado visou resgatar as representações sociais sobre mosquitos e problemas ambientais, utilizando um conjunto de instrumentos, as figuras metodológicas, que viäbilizam discriminar os principais temas do discurso apresentado pelos alunos no que se refere ao presente objeto de estudo.

As transcrições das entrevistas foram inseridas no software Qualiquantisoft e adequadamente categorizadas. 
Os instrumentos em questão são a idéia central (IC), as expressões chave (ECH) e o Discurso do Sujeito Coletivo (DSC).

A estratégia metodológica do DSC foi criada por Lefêvre \& Lefèvre (2003) para resgatar a fala do social, através da "soma qualitativa" de discursos semelhantes ou complementares obtidos de depoimentos individuais resultando, assim, o DSC.

As Expressões chave são os segmentos ou trechos de cada depoimento individual que revele a sua essência de maneira a separá-los do que é irrelevante. A essas ECH correspondem (IĆ) que são nomes ou expressões lingüísticas adequadas para descrever de maneira sintética e objetiva o sentido de um agrupamento de ECH. Com o material das ECH de cada agrupamento acrescentado termos conectivos, elabora-se o DSC.

O DSC é composto na primeira pessoa do singular, com as expressões chave de depoimentos de sentido semelhante, provenientes de diferentes indivíduos. Essa pessoa coletiva fala como se fosse um indivíduo, ou seja, como um sujeito de discurso " "natural", mas que veicula uma representação de vários indivíduos, o que permite a emergência, tanto qualitativa quanto quantitativa, de. uma opinião coletiva: qualitativa porque se trata de um discurso com conteúdo ampliado e diversificado, e quantitativa na medida em que vários sujeitos contribuíram para a construção deste DSC (Lefèvre \& Lefèvre 2006). 


\section{Aspectos Éticos}

O estudo foi aprovado pelo Comịtê de Ética da Faculdade de Saúde Pública da Universidade de,São Paulo.

Os dados foram tratados de maneira confidencial e não houve qualquer procedimento que causou riscos ou danos aos alunos, conforme exposto em Termo de Consentimento Livre e Esclarecido, devidamente apresentado e assinado pelos alunos ou responsáveis (Anexo II è Anexo III).

\section{Resultados}

\subsection{Caracterização da amostra pesquisada}

A amostra foi composta por 194 alunos, sendo $103(53,1 \%)$ do sexo feminino e $91(46,9 \%)$ do sexo masculino. Na EE. Parque Ecológico foram entrevistados 82 alunos. No bairro de Ermelino Matarazzo moram 45 (54,88\%) entrevistados, 20 (24,39\%) no Jardim Matarazzo, 7 (8,53\%) no bairro União de Vila Nova, 6 (7,32\%) na Vila Jacuí e 1 (1,22\%) aluno nos seguintes bairros: Santa Cruz, Vila Nova União, Vila Paranaguá e Vila União.

Na EE. Irmã Annete foram entrevistados 112 alunos. No bairro Jardim Keralux moram $90(80,36 \%)$ entrevistados, $5(4,47 \%)$ na Vila Cisper, $5(4,47 \%)$ no bairro de Ermelino Matarazzo, 4 (3,57\%) no Jardim Nova Tereza, 4 (3.57\%) no Jardim Verônica, 
$2(1,78 \%)$ na Vila Silvia, $1(0,89 \%)$ Jardim Guaraciaba e $1(0,89)$ aluno não informou o bairro.

A idade variou de 14 a 61 anos, apresentando maior frequiência entre 14 e 19 anos, conforme as tabelas $n^{\circ} 1$ e $n^{\circ} 2$.

Tabela 1. Idade dos alunos entrevistados na EE. Parque Ecológico.

\begin{tabular}{ccccc}
\hline Faixa etária & $1^{\circ}$ ano & $2^{\circ}$ ano & $3^{\circ}$ ano & Total \\
\hline 14 a 19 & 27 & 12 & 11 & 50 \\
20 a 29 & 8 & 8 & 4 & 20 \\
30 a 39 & 4 & 0 & 4 & 8 \\
40 e mais & 1 & 2 & 1 & 4 \\
\hline Total & 40 & 22 & 20 & 82 \\
\hline
\end{tabular}

Tabela 2. Idade dos alunos entrevistados na EE. Irmã Annete.

\begin{tabular}{ccccc}
\hline Faixa etária & $1^{\circ}$ ano & $2^{\circ}$ ano & $3^{\circ}$ ano & Total \\
\hline 14 a 19 & 37 & 22 & 23 & 82 \\
20 a 29 & 3 & 4 & 10 & 17 \\
30 a 39 & 2 & 2 & 5 & 9 \\
40 e mais & 0 & 2 & 2 & 4 \\
\hline Total & 42 & 30 & 40 & 112 \\
\hline
\end{tabular}

\subsection{Resultado Qualiquantitativos}

Decidiu-se tabular os depoimentos dos alunos das duas unidades escolares conjuntamente, uma vez que não se observou diferenças entre elas nas representações sociais sobre o tema da pesquisa.

Quanto às percentagens calculadas, para que representassem o grau de compartilhamento daś idéias dos entrevistados, foi elaborada a razão do número de respostas obtidas em cada idéia central pelo número de indivíduos (anexo IV). A análise dos depoimentos permitiu a apreciação quantitativa da variável intensidade; que é 
medida pela freqüência de respostas categorizadas em cada idéia central. Esse atributo refere-se ao grau de compartilhamento de uma mesma idéia.

Os critérios de inclusão das expressões chave, dentro de cada idéia central, para obtenção dos discursos do sujeito coletivo serão apresentados a seguir.

\section{Representaȩões Sociais sobre o ciclo reprodutivo do mosquito}

No quadro 1 encontram as idéias centrais identificadas nos discursos dos alunos das escolas Parque Ecológico Tietê e Irmã Annete, quando indagados sobre o ćiclo reprodutivo do mosquito. A seguir são apresentados os critérios de inclusão das expressões chave, dentro de cada idéia central, para obtenção dos Discursos do Sujeito Coletivo (DSC).

Quadro 1. Idéias Centrais identificadas nos discursos dós alunos das escolas Parque Ecológico Tietê e Irmã Annete, 2007.

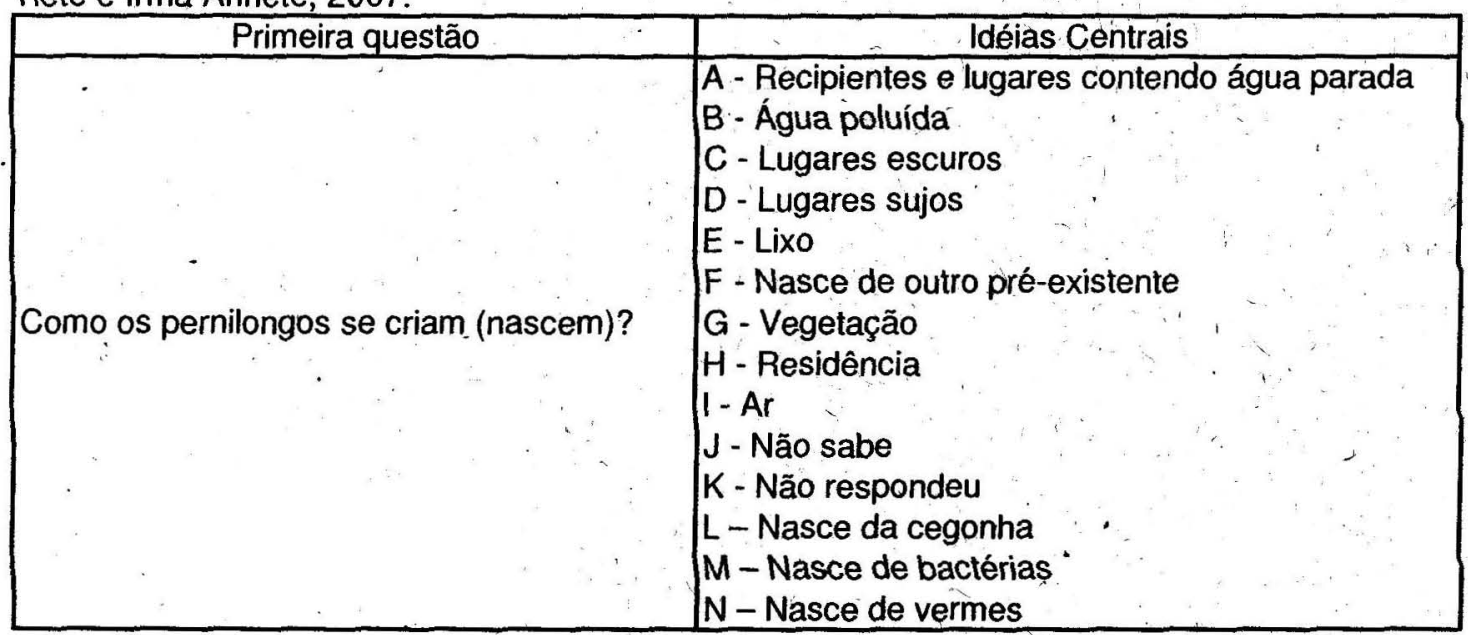




\section{Critérios de inclusão}

Idéia Central A - Recipientes e lugares contendo água parada. Foram incluídas as expressões chave nas quais os alunos citaram a necessidade da presença de recipientes e lugares contendo água.

Idéia Central B - Água poluída. Foram incluídas as expressões chave nas quais os alunos citaram a presença de água suja, poluída em brejos, córregos, lagos e rios.

Idéia Central C - Lugares escuros. Foram incluídas as expressões chave nas quais os alunos citaram lugares escuros.

Idéia Central D - Lugares sujos. Foram incluídas as expressões chave nas quais os alunos citaram a presença da sujeira (sem citar propriamente o lixo).

Idéia Central E - Lixo. Foram incluídas as expressões chave nas quais os alunos citaram o acúmulo de lixo.

Idéia Central F - Nasce de outro pré-existente. Foram incluídas as expressões chave nas quais os alunos citaram o ciclo biológico de reprodução. I (vivíparos); II (ovíparos completos); III (ovíparos incompletos).

Idéia Central G - Vegetação. Foram incluídas as expressões chave nas quais os alunos citaram vegetais (mato).

Idéia Central H - Residência. Foram incluídas as expressões chave nas quaìs os alunos citaram a casa (intradomicílio).

Idéia Central I - Ar. Foram incluídas as expressões chave nas quais os alunos citaram o 
Idéias Centrais J e K - não sabe ou não respondeu.

Idéias Centrais L, M e N. - Nasce da cegonha; nasce de bactérias; nasce de vermes. Foram incluídas as expressões chave nas quais os alunos citaram cegonha, bactérias e vermes respectivamente.

De modo geral, as categorias identificadas pelos discursos podem ser classificadas de duas formas:

1. Pelos aspectos ecológicos (onde o mosquito se prolifera) - idéias centrais A, B, C, D, E, G e H.

2. Pelo ciclo biológico reprodutivo (as fases de desenvolvimento do mosquito) idéia central - F

Primeira questão que serviu de estímulo para os alunos:

Como os pernilongos se criam (nascem)?

Idéia Central A - Recipientes e lugares contendo água parada

\section{Discurso do Sujeito Coletivo (DSC)}

INTEGRAL (EE. Parque Ecológico e EE. Irmã Annete).

Nasce na água parada tanto o pernilongo como o mosquito da dengue né? Nasce dentro de casa noś vasos de plantas eflores, nos pneus-veios do quintal, na beira de córregos, lagos, no mato, garrafas, potinhos de Danone, latas, calha d'água, caixa 
d'água aberta e todos os recipientes que tem água. Quando chove aqui ficam aquelas poças de água pela rua e em vários lugares, isso ajuda os pernilongos que vão se acumulando e aumentando. As pessoas têm que ter mais consciência e mais cuidado.

\section{EE. PARQUE ECOLÓGICO}

Nasce na água parada que acumula nos lugares né? Vasos de planta, nos pneus véio do quintal, caixas d'água descobertas, garrafas, lagos, poça de água que fica pela rua e em vários lugares como no mato aonde tem bastanté água parada. Eles nascem em todos os recipientes que tem água. Se a gente deixar água parada aí vem um mosquito lá, da dengue. As pessoas têm que ter mais consciência também e ter mais cuidado em càsa.

\section{EE. IRMÃ ANNETE}

Na minha opinião os pernilongos se criam através de águas paradas, pneus, garrafas, bacias, calhas, potinhos de Danone jogados no chão, jarrinhos, vasos de flores e plantas que não são cuidados, caixa d'água que não é lavada e vasilha cheia de água. Ah pra falar a verdade para você eu já vi muita água acumulada em muitas lajes, correndo atrás de pipa né, vi muita caixa aberta sem tampa e por aí vai.

Idéia Central B - Água poluída

\section{DSC}

\section{INTEGRAL}

Nascem da água suja, poluída, nos brejos, lagoas, esgotos ao relento e em bueiros que eles se acumulám por causa do escuro né? Eu creio que é assim que nascem nas beiras dos córregos onde tem sujeira e lixo nas favelas. Nascem no rio aí na frente, 
abandonado, o Tietê, poluído, cheio de sujeira e mau cheiro. A prefeitura podia canalizar ele para não criar mais pernilongos né.

\section{EE. PARQUE ECOLÓGICO}

Eles nascem da água suja, né? Nascem dos esgotos ao relento, através de água poluída. Eu creio que é assim que nascem nas beiras dos córregos onde tem sujeira e lixo nas favelas. Nascem no rio aí na frente, o Tietê, poluído, cheio de sujeira e mau cheiro.

\section{EE. IRMÃ ANNETE}

Nascem nos brejos, lagoas, esgotos a céu aberto e em bueiros que eles se acumulam por causa do escuro, nascem nos rios poluídos abandonados e sujos. A prefeitura podia canalizar ele para não criar mais pernilongos.

Idéia Central C - Lugares escuros

\section{DSC}

\section{INTEGRAL}

Eu acho que é nos lugares escuros que não tem claridade e mais isolados, canto de cômodo e guarda-roupa.

\section{EE. PARQUE ECOLÓGICO}

Eu acho que é nos lugares escuros, canto de cômodo. 


\section{EE. IRMÃ ANNETE}

Lugares escuros, pequenos e mais isolados como o guarda-roupa.

Idéia Central D - Lugares sujos

\section{DSC}

\section{INTEGRAL}

Eu creio que eles nascem do acúmulo da sujeira, poluição, entulhos, madeiras, coisas ruins né? Nascem em embaixo de algum lugar que não limpa, lugares que são mal cuidados, que não tem higiene e não estejam organizados, lugares que ficam sujos como garrafas, pneus e caixotes.

\section{EE. PARQUE ECOLÓGICO}

Eu creio que eles nascem através de muita sujeira, poluição, entulhos, coisas ruins né? Nascem em embaixo de algum lugar que não limpa e que não esteja organizado, lugares que ficam mais sujos como garrafas, pneus e caixotes.

\section{EE: IRMÃ ANNETE}

Nascem do acúmulo da sujeira em lugares abafados, nascem da falta de higiene nas casas, lugares que são mal cuidados.

Idéia Central E - Lixo 


\section{DSC}

\section{INTEGRAL}

Eles nascem onde as pessoas deixam o lixo que acumula nos lugares ruins, terrenos, ruas abandonadas e latas de lixo a céu aberto né? Aí eles vão se reproduzindo sempre em lugares que tem muito lixo, resíduos e comida, que.não tem a coleta, enfim que falta higiene. Tem pessoas que jogam lixo lá e esquece naquele canto e ali vai nascendo bicho $e$ vai se reproduzindo. Nós temos lixeiro aqui de segunda, quarta $e$ sexta, mas as pessoas teimam em deixar no meio da rua o lixo poluindo o meio ambiente.

\section{EE. PARQUE ECOLÓGICO}

Eles nascem do lixo que as pessoas jogam onde não devem e acumula nos lugares ruins, terrenos, ruas abandonadas e latas de lixo a céu aberto né? Aí eles vão se reproduzindo sempre em lugares que tem muito lixo e comida, que não tem a coleta de lixo, enfim que falta higiene. Tem pessoas que jogam lixo lá e esquece naquele canto $e$ ali vai nascendo bicho e vai se reproduzindo. As pessoas que não ligam poluem o meio ambiente.

\section{EE. IRMÃ ANNETE}

Eles nascem na rua, no lixão, aonde acumula lixo, resíduos e sujeira. Nós temos o lixeiro aqui de segunda, quarta e sexta e as pessoas teimam em deixar no meio da rua o lixo.

Idéia Central F - Nasce de outro pré-existente 


\section{DSC}

\section{INTEGRAL - I}

Eles fazem sexo assim e a mãe da cria né?.Um bebê nasce pela mãe, elas vão $e$ coloca os seus filhotes com seu orgãozinho na caixa d'água, vasinho de planta, garrafas e água parada né.

\section{EE. PARQUE ECOLÓGICO - I}

Eles fazem sexo assim e a mãe da cria né? Um nasce do outro da barriga da mãe onde tem água parada, rio poluído e poça de água.

\section{EE. IRMÃ ANNETE - I}

Um bebê nasce pela mãe né, elas vão e coloca os seus filhotes com seu orgãozinho na caixa d'água, vasinho de planta, garrafas e água parada né.

\section{INTEGRAL - II}

Vem um mosquito lá pica as pessoas tira o sangue e a mãe coloca os ovos lá dentro da água, nos rios, nos matos, pneus, caixa d'água sem tampa né, em poças de água que fica pela rua e saem às larvas que se desenvolvem e nascem os mosquitos.

\section{EE. PARQUE ECOLÓGICO - II}

Vem um mosquito lá pica as pessoas tira o sangue e coloca os ovos lá dentro da água, nos rios, nos matos, pneus, caixa d'água sem tampa né, em poças de água que fica pela rua e saem às larvas que vira o mosquito. 


\section{EE. IRMÃ ANNETE - II}

Eles botam ovos nas águas, córregos, rios, pneus, vaso de planta, garrafa virada aberta de boca pra cima e se transforma em larvas que se desenvolvem e nascem os mosquitos.

\section{INTEGRAL - III}

Nasce através de uma larva no rio, esgotos, lixões, plantas, vasos, pneus, garrafas velhas e aí começam se proliferar dando mais prejudicações à saúde.

\section{EE. PARQUE ECOLÓGICO - III}

Nasce através de uma larva no rio, no córgo onde tem sujeira.

\section{EE. IRMÃ ANNETE - III}

Nascem através dás larvas que eles colocam em águaș paradas, ésgotos, lixões, plantas, vasos, pneus, garrafas velhas e aí começam se proliferar dando mais prejudicações à saúde.

Idéia Central G - Vegetação

\section{DSC}

\section{INTEGRAL}

Na minha opinião é no meio do mato, nas plantas, nas árvores, florestas né? Este matagal que tem aí atrás da escola é o ambiente deles, faz parte da natureza, do meio ambiente. Cria mais por causa dos matos que têm aqui ao redor, que tem perto do rio. Nas matas sempre têm bastante pernilongo, principalmente, as matas ali que faz 
anos que não cortam, deveria ser cortado mensalmente, que é muito grande também né? Eles vão nascendo e às vezes, quando ta muito calor vão pra dentro do prédio. Antes quando não tinha mato era difícil ter pernilongo.

\section{EE. PARQUE ECOLÓGICO}

Na minha opinião é no meio do mato, nas plantas, na árvore né? Faz parte da natureza, do meio ambiente. Cria mais por causa dos matos que têm aqui ao redor, que tem perto do rio. Nas matas sempre têm bastante pernilongo, principalmente, as matas ali que faz anos que não cortam, deveria ser cortado mensalmente, que é muito grande também né? Eles vão nascendo e às vezes, quando ta muito calor vão pra dentro do prédio. Antes quando não tinha mato era difícil ter pernilongo.

\section{IRMÃ ANNETE}

Eles nascem nas árvores, no mato perto da nossa casa e no matagal atrás da escola.

Idéia Central H - Residência.

\section{DSC}

\section{INTEGRAL}

Nasce na própria casa se o tempo fechar. Tem que ter muito cuidado quando ta calor.

\section{EE. PARQUE ECOLÓGICO}

Nasce na própria casa. Tem que ter muito cuidado quando ta calor. 


\section{EE. IRMÃ INNETE}

Nasce dentro de casa se o tempo fechar.

Idéia Central I - Ar

DSC

EE. PARQUE ECOLÓGICO

Eu acho que vem do ar.

Idéia Central J - Não sabe

INTEGRAL

DSC

Não sei não como eles nascem não. Não'faço a mínima idéia.

\section{EE. PARQUE ECOLÓGICO}

`. Não sei não como eles nascem não.

\section{EE. IRMÃ ANNETE}

Não sei. Não faço a mínima idéia.

Idéia Central K - Não respondeu 
EE. PARQUE ECOLÓGICO

$\dot{E}$

Idéia Central L - Nasce da cegonha

\section{DSC}

EE. PARQUE ECOLÓgICO

Ai não sei. Acho que é pela cegonha né?

Idéia Central M - Nasce de bactérias.

DSC

EE. IRMÃ ANNETE

Acredito que eles vêm de bactérias, de alguma bactéria que deve trazer os ovinhos.

Idéia Central N - Nasce de vermes.

\section{DSC}

EE. IRMÃ ANNETE

Nascem através de vermes. 
Tabela 3. Distribuição do número e percentual de respostas compartilhadas pelos alunos por série das escolas Parque Ecológico e Irmã Annete sobre reprodução dos pernilongos, São Paulo, 2007.

\begin{tabular}{|c|c|c|c|c|c|c|c|c|}
\hline \multirow{2}{*}{ Idéias Centrais } & \multicolumn{2}{|c|}{$1^{\circ}$ ano } & \multicolumn{2}{|c|}{$2^{\circ}$ ano } & \multicolumn{2}{|c|}{$3^{\circ}$ ano } & \multicolumn{2}{|c|}{ Total } \\
\hline & $\mathrm{N}$ & $\%$ & $\mathrm{~N}$ & $\%$ & $\mathrm{~N}$ & $\%$ & $\mathrm{~N}$ & $\%$ \\
\hline A -Recipientes e lugares & & & & & & & & \\
\hline contendo água parada & 20 & 24,39 & 16 & 30,77 & 21 & 35,00 & 57 & 29,38 \\
\hline B - Água poluída & 23 & 28,05 & 13 & 25,00 & 24 & 40,00 & 60 & 30,93 \\
\hline C - Lugares escuros & 2 & 2,44 & 4 & 7,69 & 2 & 3,33 & 8 & 4,12 \\
\hline D - Lugares sujos & 10 & 12,20 & 8 & 15,38 & 6 & 10,00 & 24 & 12,37 \\
\hline E - Lixo & 11 & 13,41 . & 6 & 11,54 & 13 & 21,67 & 30 & 15,46 \\
\hline F - Nasce de outro pré- & & & & & & & & \\
\hline existe & 24 & 29,27 & 20 & 38,46 & 14 & 23,33 & 58 & 29,90 \\
\hline G - Vegetação & 27 & 32,93 & 11 & 21,15 & 23 & 38,33 & 61 & 31,44 \\
\hline H - Residência & 2 & 2,44 & 0 & 0,00 & 0 & 0,00 & 2 & 1,03 \\
\hline I- Ar & 1 & 1,22 & 0 & 0,00 & 0 & 0,00 & 1 & 0,52 \\
\hline J - Não sabe & 3 & 3,66 & 2 & 3,85 & 2 & 3,33 & 7 & 3,61 \\
\hline K - Não respondeu & 1 & 1,22 & 0 & 0,00 & 0 & 0,00 & 1 & 0,52 \\
\hline L - Nasce da cegonha & 0 & 0,00 & 0 & 0,00 & 1 & 1,67 & 1 & 0,52 \\
\hline M - Nasce de bactérias & 0 & 0,00 & 1 & 1,92 & 1 & 1,67 & 2 & 1,03 \\
\hline $\mathrm{N}$ - Nasce de vermes & 0 & 0,00 & 0 & 0,00 & 1 & 1,67 & 1 & 0,52 \\
\hline Total & 124 & $151,22^{\star}$ & 81 & $155,77^{\star}$ & 108 & $180,00^{\star}$ & 313 & $161,34^{*}$ \\
\hline
\end{tabular}

* Há variações nas freqüências, pois o mesmo indivíduo pode ter mais de uma idéia central para a mesma pergunta.

\section{Representações sociais sobre os problemas provocados por mosquito}

No quadro 2 encontram as idéias centrais identificadas nos discursos dos alunos das escolas Parque Ecológico Tietê e Irmã Annete, quando indagados sobre os problemas provocados por mosquito. A seguir são apresentados os critérios de inclusão das expressões chave, dentro de cada idéia central, para obtenção dos Discursos do Sujeito Coletivo (DSC). 
Quadro 2. Idéias Centrais identificadas nos discursos dos alunos das'escolas Parque Ecológico Tietê e Irmã Annete, 2007.

\begin{tabular}{|c|c|}
\hline Segunda questão & 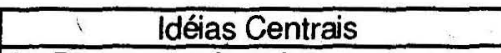 \\
\hline & $\begin{array}{l}\text { A - Provoca incômodo. } \\
\text { B - Näo provoca } \\
\text { C - Provoca doença. }\end{array}$ \\
\hline Os pernilongos podem provocar problemas para as & D - Provoca dengue. \\
\hline pessoas? Caso afirmativo? Quais? & $\begin{array}{l}\text { E- Provoca febre amarela. } \\
\text { F-Provoca malária e leishmaniose }\end{array}$ \\
\hline$\cdots$ & $\begin{array}{l}\text { G - Provoca doença de chagas. } \\
\text { H - Provoca gripe, aids etc. } \\
1 \text { - Provoca febre, dor de cabeça etc }\end{array}$ \\
\hline
\end{tabular}

\section{Critérios de inclusão}

Idéia Central A - Provoca incômodo. Foram incluídas as expressões chave nas quais os alunos citaram irritabilidade, coceira e alergia.

Idéia Central B - Não provoca. Foram incluídas as expressões chave nas quais os alunos citaram que os mosquitos não provocavam problemas.

Idéia Central C - Provoca doença. Foram incluídas as expressões chave nas quais os alunos citaram doença, mas sem especificá-la.

Idéia Central D - Provoca dengue. Foram incluídas as expressões chave nas quais os alunos citaram especificamente a dengue.

Idéia Central E - Provoca febre amarela. Foram incluídas as expressões chave nas quais os alunos citaram especificamente a febre amarela.

Idéia Central F - Provoca malária e leishmaniose. Foram incluídas as expressões chave nas quais os alunos citaram malária e leishmaniose. 
Idéia Central G - Provoca doença de chagas. Foram incluídas as expressões chave nas quais os alunos citaram a doença de chagas.

Idéia Central H - Provoca gripe, AIDS etc. Foram incluídas as expressões chave nas quais os alunos citaram doenças não transmissíveis por insetos.

Idéia Central I - Provoca febre, dór de cabeça etc. Foram incluídas as expressões chave nas quais os alunos citaram apenas sintomas de doenças.

De modo geral, as categorias identificadas pelos discursos podem ser classificadas de duas formas:

1. Pelo incômodo provocado - idéia central A

2. Pelas doenças transmissíveis - idéias centrais: C, D, E e F

Segunda questão que serviu de estímulo para os alunos:

Os pernilongos podem provocar problemas para as pessoas? Caso afirmativo. Quais?

Idéia Central A - Provoca incômodo

\section{DSC}

\section{INTEGRAL}

Ah eu acho que muito, picada dá alergia né, coceira, calombo, problema na pele, além de não deixar ninguém dormir de noite né, fica mexendo no psicológico das pessoas que não tem uma dormida normal como das outras pessoas. Minha filha mesmo tem alergia, quando ela é picada de pernilongo cria uns caroços né, fica toda inchada. Eu tenho uma irmã que ela é novinha, ela fica cheia de carocinhos na pele é ruim. Muitas pessoas sentem desconforto, quando ele pica fica ferido o local e avermelhado. 
Eles tomam conta do nosso ar, ele vai começar entrar no nosso ouvido, aí isso pode ser um pouco perigoso, ai eu falo pra ele depois eu te pego malandro.

\title{
EE. PARQUE ECOLÓGICO
}

Ah eu acho que muito, picada dá alergia né, coceira, calombo, irritação na pele, além de incomodar na hora de dormir. Minha filha mesmo tem alergia, quando ela é picada de pernilongo cria uns caroços né, fica toda inchada. Muitas pèssoas sentem desconforto, quando ele pica fica ferido o local e avermelhado.

\section{EE. IRMÃ ANNETE}

Eles tomam conta do nosso ar vão começar entrâr no nosso ouvido, aí isso pode ser um pouco perigoso, fica mexendo no psicológico das pessoas, muito incômodo, pica a noite inteira, não deixa dormir fica zuando no ouvido dos outros. A minha filha tem problema de alergia de tanto coçar chega a ter ferida, então atrapalha muito nossa vida né. Provoca alergia, irritação, coceira, problema na pele que fica toda encaroçada. Tenho uma irmã que ela é alérgica se ela levar uma picada tem que para no hospital.

Idéia Central B - Não provoca

\section{DSC}

\section{INTEGRAL}

Na minha opinião não, acredito que não.

\section{EE. PARQUE ECOLÓGICOO}

Não conheço, acredito que não.

\author{
EE. IRMÃ ANNETE
}


Na minha opinião não.

Idéia Central C - Provoca doença

\section{DSC}

\section{INTEGRAL}

Provocam muitas doenças, capaz até de você emagrecer bastante e levar a morte. Ele chupa o sangue de muitas pessoas aí ele pode também transmitir doenças, dá dor de cabeça na pessọa, dor no corpo, tontura, mal-estar, febre alta, problemas de saúde, a pessoa não vai poder sair da cama.

\section{EE. PARQUE ECOLÓGICO}

Provoca doença. Ele chupa o sangue de muitas pessoas aí ele pode tambèm transmitir doenças, dá dor de cabeça na pessoa, dor no corpo, tontura, mal-estar, problemas de saúde, a péssoa não vai poder sair da cama.

\section{EE. IRMÃ ANNETE}

Transmite doenças, dá febre, dor de cabeça, cansaço. Se ele picar alguém que esteja doente e picar outra pessoa, transmite doença, principalmente pra crianças né. Ele pica eu, eu tenho um tipo de sangue, ele pica você, vai que eu tenho alguma coisa no meu sangue, transmite. Se ele pïcar um cachorro contaminado e depois for lá picar eu, acho que pode transmitir doença.

Idéia Central D - Provoca dengue. 


\section{INTEGRAL}

Eles são nojentos provocam dengue, pode dar tontura, febre, dor de cabeça, dor no corpo, provoca vômito e pode até matar se não for cuidado. Minha família e várias pessoas já pegaram dengue. Se picar éu que tènho a doença, depois picar você, se pode contrair a doença, se as duas pessoas tiverem saudáveis eu ach que não, passa dengue se tiver com dengue.

\section{EE. PARQUE ECOLÓGICO}

Provoca dengue, pode dar tontura, febre, dor de cabeça, dor no corpo, provoca . vômito e pode até matar se não for cuidado.

\section{EE. IRMÃ ANNETE}

Eles são nojentos. Minha família e várias pessoas já pegaram dengue. Se picar eu que tenho a doença depois picar você, se pode contrair a doença, se as duas pessoas tiverem saudáveis eu acho qúe não, passa dengue se tiver com dengue né. Pode causar vários problemas aí pra saúde da gente.

Idéia Central E - Provoca febre amarela

\section{DSC}

\section{INTEGRAL}

Provoca febre amarela. 


\section{EE. PARQUE ECOLÓGICO}

Provoca febre amarela.

EE. IRMÃ ANNETE

Provoca febre amarela.

Idéia Central F- Provoca malária e leishmaniose.

\section{DSC}

\section{EE. IRMÃ ANNETE}

Provoca leishmaniose devido aos animais serem contaminados. $O$ inseto picando ele, picando outro ser humano vai transmitir a doença e não só essa, tem o pernilongo da malária. Na verdade acho que a maioria dos insetos existe pra prejudicar a saúde mesmo.

Idéia Central G - Provoca doença de chagas

\section{DSC}

\section{EE. PARQUE ECOLÓGICO}

Provoca doença de chagas.

Idéia Central H - Provoca gripe, AIDS etc 


\section{DSC}

\section{INTEGRAL}

Provoca AIDS, transmissão do vírus HIV em primeiro lugar né e aí outras doenças transmissíveis que eu também não conheço. Muitas pessoas têm doenças né aí eles vão picam a pessoa que tem uma doença, certa doença, aí vai pica a outra que não tem, eu acho que com isso pode passar a doença, por exemplo, a AIDS né, eu acho que pode ser transmitido pelo mosquito também. Pica alguém contaminado né e depois a gente, vai ser tipo meio que uma transfusão de sangue.

\section{EE. PARQUE ECOLÓGICO}

Provoca AIDS, transmissão do vírus HW em primeiro lugar né e aí outras doenças transmissíveis que eu também nẫo conheço, tipo assim, cê tem uma doença e ele te pica, quando ele picar você ele transmite aquela doença, tipo AIDS e gripe também.

\section{EE. IRMÃ ANNETE}

Pode transmitir doenças. Pode ser que transmita HIV. Muitas pessoas têm doenças né aí eles vão picam as pessoas que tem uma doença, certa doença, aí vai pica a outra que não tem, eu acho que com isso pode passar a doença, por exemplo, a AIDS né, eu acho que pode ser transmitido pelo mosquito também, vai ser tipo meio que uma transfusão de sangue através da picada.

Idéia Central I - Provoca febre, dor de cabeça etc 


\section{DSC}

\section{INTEGRAL}

Eles provocam cansaço, febre, dor de cabeça, tontura, dores musculares e vômito.

\section{EE. PARQUE ECOLÓGICO}

Eles provocam febre, dor de cabeça e tontura.

\section{EE. IRMÃ ANNETE}

Eles provocam cansaço, febre, dor de cabeça, dores musculares e vômito.

Tabela 4. Distrịbuição do número e percentual de respostas compartilhadas pelos alunos por série das escolas Parque Ecológico e Irmã Annete sobre problemas provocados pọr pernilongos, São Paulo, 2007.

\begin{tabular}{|c|c|c|c|c|c|c|c|c|}
\hline \multirow[b]{2}{*}{ - Idéias Centrais } & \multicolumn{2}{|c|}{$1^{2}$ ano } & \multicolumn{2}{|c|}{$2^{2}$ ano } & \multicolumn{2}{|c|}{$3^{\circ}$ ano } & \multicolumn{2}{|c|}{ Total } \\
\hline & $\mathrm{N}$. & $\%$ & $\mathrm{~N}$ & $\%$ & $\mathrm{~N}$ & $\%$ & $\mathrm{~N}$ & $\%$ \\
\hline A - Provoca incômodo & 37 & 45,12 & 25 & 48,08 & 29 & 48,33 & 91 & 46,91 \\
\hline B - Não provoca & 5 & 6,10 & 6 & 11,54 & 5 & 8,33 & 16 & 8,25 \\
\hline C - Provoca doença & 26 & 31,71 & 11. & 21,15 & 19 & 31,67 & 56 & 28,87 \\
\hline D - Provoca dengue & 31 & 37,80 & 13 & 25,00 & 18 & 30,00 & 62 & 31,96 \\
\hline E - Provoca febre amarela & 0 & 0,00 & 1 & 1,92 & 1 & 1,67 & 2 & 1,03 \\
\hline F - Provoca malária e leishmaniose & 1 & 1,22 & 1 & 1,92 & 1 & 1,67 & 3 & 1,55 \\
\hline G - Provoca doença de chagas & 0 & 0,00 & 0 & 0,00 & 2 & 3,33 & 2 & 1,03 \\
\hline H - Provoca gripe, aids etc & 7 & 8,54 & 8 & 15,38 & 5 & 8,33 & 20 & 10,31 \\
\hline 1 - Provoca febre, dor de cabeça etc & 3 & 3,66 & 6 & 11,54 & 5 & 8,33 & 14 & 7,22 \\
\hline Total & 110 & $134,15^{\star}$ & 71 & $136,54^{*}$ & 85 & $141,67^{*}$ & 266 & $137,11^{*}$ \\
\hline
\end{tabular}

* Há variações nas freqüências, pois o mesmo indivíduo pode ter mais de uma idéia central para a mesma pergunta.

No quadro 3 encontram as idéias centrais identificadas nos discursos dos alunos das escolas Parque Ecológico Tietê e Irmã Annete, quando indagados sobre o controłe 
de mosquito. A seguir são apresentados os crițérios de inclusão das expressões chave, dentro de cada idéia central, para obtenção dos Discursos do Sujeito Coletivo (DSC).

Quadro 3. Idéias Centrais identificadas nos discursos dos alunos das escolas Parque Ecológico Tietê e Irmã Annete, 2007.

\begin{tabular}{|l|l|}
\hline \multicolumn{1}{|c|}{ Terceira questão } & \multicolumn{1}{c|}{ Idéias Centrais } \\
\hline \multirow{3}{*}{$\begin{array}{l}\text { O que pode ser feito para acabar com os } \\
\text { pernilongos? }\end{array}$} & A - Usar inseticidas. \\
& B - Não acumular água. \\
C - Não acumular lixo. \\
D - Limpar a vegetação. \\
& E - Ter consciência da situação. \\
& F - Saneamento ambiental. \\
& G - Usar telas nas portas, janelas e mosquiteiros \\
& H - Canalizar rios e esgotos. \\
& I - Eliminar mecanicamente. \\
& J - O governo atuar. \\
& K - Nada pode ser feito. \\
\hline
\end{tabular}

Idéia Central A - Usar inseticidas. Foram incluídas as expressões chave nas quais os alunos citaram o uso de produtos químicos.

Idéia Central B - Não acumular água. Foram incluídas as expressões chave nas quais os alunos evidenciaram a importância de evitar o acumulo de água.

Idéia Central C - Não acumular lixo. Foram incluídas as expressões chave nas quais os alunos evidenciaram a importância de evitar o acumulo de lixo

Idéia Central D - Limpar a vegetação. Foram incluídas as éxpressões chave nas quais os alunos evidenciaram a importância do controle no crescimento das gramíneas.

Idéia Central E - Ter consciência da situação. Foram incluídas as expressões chave nas quais os alunos evidenciaram a importância da responsabilidade ambiental.

Idéia Central F - Saneamento ambiental. Foram incluídas as expressões chave nas quais os alunos evidenciaram a importância do saneamento básico.' 
Idéia Central G - Usar telas nas portas, janelas e mosquiteiros. Foram incluídas as expressões chave nas quais os alunos citaram o uso de telas e mosquiteiros.

Idéia Central H - Canalizar rios e esgotos. Foram incluídas as expressões chave nas quais os alunos citaram a canalização dos rios e esgotos.

Idéia Central I - Eliminar mecanicamente. Foram incluídas as expressões chave nas quais os alunos citaram a eliminação mecânica dos mosquitos.

Idéia Central J - O Governo atuar. Foram incluídas as expressões chave nas quais os alunos citaram a importância da participação governamental.

Idéia Central K - Nada pode ser feito. Fořam incluídas as expressões chave nas quais os alunos citaram não tem como eliminar os mosquitos.

Terceira questão que sẹrviu de estímulo para os alunos:

O que pode ser feito para acabar com os pernilongos?

Idéia Central A - Usar inseticidas

DSC

\section{INTEGRAL}

Inseticida, porque eu acho que acabar com eles mesmos não acaba é só pra dormir. Dentro de casa eu fecho a janela cedo e passo veneno, compro aqueles produtos químicos, spray que fala né, espiral ou aquelas cobrinhas que fede muito, às vezes, ligo aqueles interruptorzinhos de tomada que vem uma pastilha, acho que dura só doze 
horas. Tem que fazer uma dedetização pelo bairro inteiro, pela comunidade inteira, passar carros bombas com veneno pra matar.

\section{EE. PARQUE ECOLÓGICO}

Dedetização né, na minha casa èu passo veneno, inseticida, compro áqueles produtos, spray que fala né, espiral ou aquelas cobrinhas que fede muito, às vezes, ligo aqueles interruptorzinhos de tomada que vem uma pastilha, acho que dura só doze horas.

\section{EE. IRMÃ ANNETE}

Acabar com eles mesmos não acaba é só pra dormir, a gente usa aqueles venenos, inseticidas, produtos químicos né, spray, repelente que liga na tomada, minhoquinha que queima etc. Eu acho que polui mais, mas é o único meio que tem pra dormir à noite, né. Tem que fazer uma dedetização pelo bairro inteiro, pela comunidade inteira, passar carros bombas com veneno pra matar.

Idéia Central B - Não acumular água

\section{DSC}

\section{INTEGRAL}

Nunca vai acabar a gente têm que sempre dar uma regularizada pra manter poucos. Não deixar água parada, tirar tudo que acumula água no quintal quando chove, tampar os pneus, caixa d'água, virar as garrafas para baixo, cuidar das plantas, derramar a água dos baldes, potes, latas e tirar a água da lage. Eu faço a minha parte como diz na televisão. 


\section{EE. PARQUE ECOLÓGICO}

Não deixar água parada, tirar tudo que acumula água no quintal quando chove, tampar os pneus, caixa d'água, virar as garrafas para baixo, limpar os vasinhos, colocar areia, derramar a água dos baldes, potes, latais e tirar a água da lage. Eu faço a minha parte como diz na televisão.

\section{EE. IRMÃ ANNETE}

Nunca vai acabar a gente têm que sempre dar uma regularizada pra manter poucos. Cuidar dos pratinhos das plantas, dos pneus, tirar a água dos vasilhames, fechar a caixa d'água direito. Evito o máximo possível deixar água parada.

Idéia Central C - Não acumular lixo

\section{DSC}

\section{INTEGRAL}

Limpeza, usar cândida né, não deixar juntar lixo no quintal, deixar tudo limpo, lixo separado, tirado imediatamente, colocar tudo nos devidos lugares né, aí eles somem. O mais importante é manter a limpeza né, deixar o ambiente mais limpo, conservado né.

\section{EE. PARQUE ECOLÓGICO}

Limpeza né, não deixar juntar lixo no quintal, deixar tudo limpo, lixo separádo, tirado imediatamente, colocar tudo nos devidos lugares né, aí eles somem. O mais importante é acabar com o lixo. 


\section{EE. IRMÃ ANNETE}

Mantendo a limpeza né, o máximo possível, não deixar acumular sujeïra na laje e embaixo da escada, limpeza nos esgotos: Evitar jogar muito lixo na rua, deixar o ambiente mais limpo, conservado né.

Idéia Central D - Limpar a vegetação

\section{DSC}

\section{INTEGRAL}

Cortar os matos o-máximo que for possivel, na beira do rio tem muito e acumula bastante pernilongo.

\section{EE. PARQUE ECOLÓGICO}

Capinar este mato do rio, a beira tem muito e através deste mato acumula muito pernilongo.

\section{EE. IRMÃ ANNETE}

Cortar os matos, eliminar o máximo que for possível, não deixar capim perto da sua casa.

Idéia Central E - Ter consciência da situação 


\section{DSC}

\section{INTEGRAL}

A humanidade tem que se conscientizar e tentar limpar mais as casas, deixar mais organizada, não deixar água e lixo acumulados em casa, começar a cuidar bem das plantas, lavar as calçadas direito, jogar pneu no lixo, limpar a caixa da água, coisas simples, responsabilidade é fundamental pra isso. Se todo mundo se unir e colaborar, não jogar sujeira no meio da rua, sempre limpar né, sempre ajudar a comunidade e fazer o que é certo. Os vizinhos têm que falar pro outro, conscientizar né. Cada um deve fazer sua parte porque exterminar é difícil, pelo menos diminui né. Se nós dermos as mãos podemos não acabar, mas amenizar aí por setenta por cento esse grande problema.

\section{EE. PARQUE ECOLÓGICO}

Eu acho que vem do próprio pessoal tomar consciência e começar a cuidar mais, responsabilidade é fundamental pra isso. Se todo mundo se unir e colaborar, não jogar sujeira no meio da rua, sempre limpar né, sempre ajudar a comunidade e fazer o que é certo. Os vizinhos têm que falar pro outro, conscientizar né.

\section{EE. IRMÃ ANNETE}

A humanidade se conscientizar, coisas simples, limpar mais as casas, não deixar água acumulada e não acumular lixo. Começar a cuidar bem das plantas, lavar calçadas direito, jogar pneu no lixo, limpar a caixa da água, deixar os bairros mais limpos, cuidar né do lugar onde você vive. Se nós dermos as mãos podemos não acabar, mas amenizar aí por setenta por cento esse grande problema. 
Idéia Central F- Saneamento ambiental

\section{DSC}

\section{INTEGRAL}

Saneamento básico né, deixar o meio ambiente limpo, tirar o acúmulo de lixo, de entulho, cuidar da vegetação, melhorar a qualidade dos esgotos, dos rios, tratar bem da água, urbanizar o lugar que mora e evitar a poluição preservando a natureza.

\section{EE. PARQUE ECOLÓGICO}

Saneamento básico né, deixar o meio ambiente limpo, tirar o acúmulo de lixo, de entulho, cortar esses matos; melhorar a qualidade dos esgotos, dos rios, tratar bem da água, urbanizar o lugar que mora e evitar a poluição.

\section{EE. IRMÃ ANNETE}

Saneamento básico né, cuidar do meio ambiente, limpar esses rios, acabar como lixo em córrego, cuidar das plantas direito acabando com os pontos de poluição preservando a natureza.

Idéia Central G - Usar telas nas portas, janelas e mosquiteiros

\section{DSC}

\section{INTEGRAL}

Colocar mosquiteiro, telas nas portas, janelas e todos os lugares. 


\section{EE. PARQUE ECOLÓGICO}

Colocar mosquiteiro, telas nas portas, janelas e todos os lugares.

EE. IRMÃ ANNETE

Cóloco tela nas janelas.

Idéia Central H - Canalizar rios e esgotos

\section{DSC}

\section{EE. IRMÃ ANNETE}

Canalizar os rios, esgotos, córregos e tampar bueiros.

Idéia Central I - Eliminar mecanicamente.

\section{DSC}

\section{INTEGRAL}

Normalmente eu mato eles, mato com o pano, dou umas brusadas na parede, ás vezes com chinelo.

\section{EE. PARQUE ECOLÓGICO}

Normálmente eu mato eles, mato com o pano, ás vezes com chinelo. 


\section{EE. IRMÃ ANNETE}

Dou umas brusadas na parede.

Idéia Central J - O Governo atuar

\section{DSC}

\section{INTEGRAL}

O governo poderia ta fazendo limpeza urbana, corte mensalmente do mato, evitar lixo nas ruas, limpar os bueiros, córregos e as áreas que são abandonadas.

\section{EE. PARQUE ECOLÓGICOO}

O governo poderia ta fazendo um corte mensalmente do mato, evitar lixo nas ruas, limpar os bueiros e as áreas que são abandonadas.

\section{EE. IRMÃ ANNETE}

$O$ prefeito não enxerga os bairros mais afastados dos grandes centros. A prefeitura deve fazer limpeza urbana, mandar uns caras pra limpar os córregos $e$ retirar entulho.

Idéia Central K - Nada pode ser feito 


\section{DSC}

\section{INTEGRAL}

Difícil. Eu acho que não pode ser feito nada porque o pernilongo faz parte da natureza, por mais que se tenta matá-lo sempre vai se reproduzir de uma maneira mais lenta ou mais rápida, não tem como acabar.

\section{EE. PARQUE ECOLÓGICO}

Não tem. Difícil.

\section{EE. IRMÃ ANNETE}

Eu acho que não pode ser feito nada porque o pernilongo faz parte da natureza, por mais que se tenta matá-lo sempre vai se reproduzir de uma maneira mais lenta ou mais rápida, não tem como acabar. 
Tabela 5. Distribuição do número e percentual de respostas compartilhadas pelos alunos por série das escolas Parque Ecológico e Irmã Annete sobre controle de pernilongos, São Paulo, 2007.

\begin{tabular}{lcccccccc}
\hline \multicolumn{1}{c}{ Idéias centrais } & \multicolumn{2}{c}{$1^{2}$ ano } & \multicolumn{2}{c}{$2^{2}$ ano } & \multicolumn{2}{c}{$3^{\circ}$ ano } & \multicolumn{2}{c}{ Total } \\
& $N$ & $\%$ & $N$ & $\%$ & $N$ & $\%$ & $N$ & $\%$ \\
\hline A - Usar inseticidas & 49 & 59,76 & 22 & 42,31 & 28 & 46,67 & 99 & 51,03 \\
B - Não acumular água & 26 & 31,71 & 18 & 34,62 & 19 & 31,67 & 63 & 32,47 \\
C - Não acumular lixo & 16 & 19,51 & 16 & 30,77 & 12 & 20,00 & 44 & 22,68 \\
D - Limpar a vegetação & 6 & 7,32 & 5 & 9,62 & 8 & 13,33 & 19 & 9,79 \\
E - Ter consciência da & & & & & & & & \\
$\quad$ situação & 6 & 7,32 & 11 & 21,15 & 9 & 15,00 & 26 & 13,40 \\
F - Saneamento ambiental & 11 & 13,41 & 7 & 13,46 & 5 & 8,33 & 23 & 11,86 \\
G - Usar telas nas portas, & & & & & & & & \\
$\quad$ janelas e mosquiteiros & 2 & 2,44 & 4 & 7,69 & 1 & 1,67 & 7 & 3,61 \\
H - Canalizar rios e esgotos & 1 & 1,22 & 1 & 1,92 & 4 & 6,67 & 6 & 3,09 \\
I- Eliminar mecanicamente & 2 & 2,44 & 1 & 1,92 & & 0,00 & 3 & 1,55 \\
J - O governo atuar & 1 & 1,22 & 1 & 1,92 & 3 & 5,00 & 5 & 2,58 \\
K- Nada pode ser feito & 0 & 0,00 & 0 & 0,00 & 3 & 5,00 & 3 & 1,55 \\
\hline \multicolumn{1}{c}{ Total } & 120 & $146,34^{*}$ & 86 & $165,38^{*}$ & 92 & $153,33^{*}$ & 298 & $153,61^{*}$ \\
\hline
\end{tabular}

* Há variações nas frequiências, pois o mesmo indivíduo pode ter mais de uma idéia central para a mesma pergunta.

No quadro 4 encontram as idéias centrais identificadas nos discursos dos alunos das escolas Parque Ecológico Tietê e Irmã Annete, quando indagados sobre os horário da hematofagia do mosquito. A seguir são apresentados os critérios de inclusão-das expressões chave, dentro de cada idéia central, para obtenção dos Discursos do Sujeito Coletivo (DSC).

Quadro 4. Idéias Centrais identificadas nos discursos dos alunos das escolas Parque Ecológico Tietê e Irmã Annete, 2007.

\begin{tabular}{|l|l|}
\hline \multicolumn{1}{|c|}{ Quarta questāo } & \multicolumn{1}{c|}{ Idéias Centrais } \\
\hline Na sua casa os pernilongos costumam picar & $\begin{array}{l}\text { A - Durante a noite. } \\
\text { B - Durante o dia e a noite. } \\
\text { as pessoas durante o dia ou durante a noite? }\end{array}$ \\
\hline
\end{tabular}




\section{Critério de inclusão}

Idéia Central A - Durante a noite. Foram incluídas as expressões chave nas quais os alunos citaram a presença de mosquitos de hábitos noturnos.

Idéia Central B - Durante o dia e a noite. Foram incluídas as expressões chave nas quais os alunos citaram a presença de mosquitos de hábitos diurnos e noturnos.

Idéia Central C - Durante o dia. Foram incluídas as expressões chave nas quais os alunos citaram a presença de mosquitos de hábitos diurnos.

Idéia Central D - Não respondeu.

Quarta questão que serviu de estímulo para os alunos:

$\mathrm{Na}$ sua casa os pernilongos costumam picar as pessoas durante o dia ou durante a noite?

Idéia Central A - Durante a noite

\section{DSC}

\section{INTEGRAL}

À noite desde o horário que a gente vai dormir até a gente cair no sono. Picam das sete até de madrugada, até de manhã cedo, principalmente quando ta calor. 


\section{EE. PARQUE ECOLÓGICO}

À noite na hora de dormir começa atacar, depois das sete horas mais ou menos é a noite toda, vai pra madrugada inteira, principalmente quando ta calor.

\section{EE. IRMÃ ANNETE}

Quando cai a noite, umas sete horas já começam aparecer aquele monte né, desde o horário que a gente vai dormir até a gente cair num sono eles tão picando e picam o resto da madrugada é mó ruim.

Idéia Central B - Durante o dia e a noite

\section{DSC}

\section{INTEGRAL}

Picam de dia, mas também à noite, nos dois horários pela manhã porque eles ficam escondidos onde ta escuro, debaixo do sofá, dentro do rack, embaixo da cama, e à noite não dá nem pra dormir.

\section{EE. PARQUE ECOLÓGICO}

Picam de dia, mas também à noite, nos dois horários pela manhã porque eles ficam escondidos onde ta escuro, debaixo do sofá, dentro do rack, embaixo da cama, e à noite porque eles entram dentro de casa. 


\section{EE. IRMÃ ANNETE}

Diariamente, independente de horário, vinte e quatro horas, picam um pouco de dia, mas picam mais à noite.

Idéia Central C - Durante o dia

\section{DSC}

\section{INTEGRAL}

A gente que pensa què ele vem à noite né, mas ele vem durante o dia, de tarde às duas horas, três horas ou quatro às cinco horas, eu desconfio que não é o pernilongo, é outro inseto, no caso a dengue né.

\section{EE. PARQUE ECOLÓGICO}

A gente que pensa que ele vem à noite né, mas ele vem durante o dia, duas horas, três horas ou quatro às cinco horas.

\section{EE. IRMÃ ANNETE}

Durante o dia, mas eu desconfio que nấo seja o pernilongo, é outro inseto, no caso a dengue né.

Idéia Central D - Não respondeu 
DSC

\section{INTEGRAL}

Não sei por que eu trab̄alho durante o dia, à noite eu só durmo. Coloca o aparelho né, nas tomadas.

\section{EE. PARQUE ECOLÓGICO}

Coloca o aparelho né, nas tomadas.

\section{EE. IRMÃ ANNETE}

Não sei por que eu trabalho durante o dia, à noite eu só durmo.

Tabela 6. Distribuição do número e percentual de respostas compartilhadas pelos alunos por série das escolas Parque Ecológico e Irmã Annete sobre o período de hematofagia de pernilongos, São Paulo, 2007.

\begin{tabular}{lcccccccc}
\multicolumn{1}{c}{ Idéias Centrais } & \multicolumn{2}{c}{$1^{2}$ ano } & \multicolumn{2}{c}{$2^{2}$ ano } & \multicolumn{2}{c}{$3^{\circ}$ ano } & \multicolumn{2}{c}{ Total } \\
\hline A - Durante a noite & N & $\%$ & N & $\%$ & N & $\%$ & N & $\%$ \\
B - Durante o dia e a noite & 3 & 91,46 & 40 & 76,92 & 51 & 85,00 & 166 & 85,57 \\
C - Durante o dia & 3 & 3,66 & 8 & 15,38 & 7 & 11,67 & 18 & 9,28 \\
D - Näo respondeu & 1 & 1,22 & 1 & 1,92 & 0 & 0,00 & 2 & 1,03 \\
\hline \multicolumn{1}{c}{ Total } & 82 & 100,00 & 52 & 100,00 & 60 & 100,00 & 194 & 100,00 \\
\hline
\end{tabular}


No quadro 5 encontram as idéias centrais identificadas nos discursos dos alunos das escolas Parque Ecológico Tietê e Irmã Annete, quando indagados sobre problemas ambientais relacionados a proliferação de mosquito. A seguir são apresentados os critérios de inclusão das expressões chave, dentro de cada idéia central, para obtenção dos Discursos do Sujeito Coletivo (DSC).

Quadro 5. Idéias Centrais identificadas nos discursos dos alunos das escolas Parque Ecológico Tietê e Irmã Annete, 2007.

\begin{tabular}{|l|l|}
\hline \multicolumn{1}{|c|}{ Quinta questão } & \multicolumn{1}{c|}{ Idéias Centrais } \\
\hline & A - Acredita que sim, mas não explicou a associação. \\
Você acha que alguns problemas ambientais estão & B - Água acumulada, lixo, gramíneas, poluição dos \\
dos rios e cótregos. \\
relacionados à criação de pernilongos? De que \\
maneira? & $\begin{array}{l}\text { C - Não desmatar, preservar o bairro e a natureza. } \\
\text { D - Poluição do ar e aquecimento global. } \\
\text { E - Acredita que não. } \\
\text { F - Não sabe se há associação. }\end{array}$ \\
\hline
\end{tabular}

\section{Critério de inclusão}

Idéia Central A - Acredita que sim, mas não explicou a associação. Foram incluídas as expressões chave nas quais os alunos citaram que há relação entre problemas ambientais e reprodução dos mosquitos, mas não exemplificaram.

Idéia Central B - Água acumulada, lixo, gramíneas, poluição dos rios e córregos. Foram incluídas as expressões chave nas quais os alụnos citaram o acumulo de água, de lixo, de mato e poluição dos rios e córregos.

Idéia Central C - Não desmatar, preservar o bairro e a natureza. Foram incluídas as expressões chave nas quais os alunos citaram a importância da preservação ambiental.

Idéia Central D - Poluição do ar e aquecimento global. Foram incluídas as expressões chave nas quais os alunos citaram impactos ocorridos na atmosfera. 
Idéia Central E - Acredita que não há relação.

Idéia Central F - Não sabe.

Quinta questão que serviu de estímulo para os alunos:

Você acha que alguns problemas ambientais estão relacionados à criação de pernilongos? De que maneira?

Idéia Central A - Acredita que sim, mas não explicou a associação

\section{DSC}

\section{INTEGRAL}

Não sei explicar mais acredito que sim, nesses lugares que têm problemas ambientais também existem pernilongos, então pode está associado.

\section{EE. PARQUE ECOLÓGICO}

Eu acredito que sim, agorá só não sei explicar, nesses' lugares que têm problemas ambientais também existem pernilongos, então pode está associado.

\section{EE. IRMÃ ANNETE}

Não sei explicar mais acredito que sim.

Idéia Central B - Água acumulada, lixo, gramíneas, poluição de rios e córregos 


\section{DSC}

\section{INTEGRAL}

Sim, por causa da poluição, lixo e água acumulada, matagal, sujeira que tem nos rios e córregos, muita gente que joga os excrementos, essas coisas direto no rio, os mosquitos, ratos gostam aí fica aquela coisa horrível. $O$ rio Tietê fica as vacas se a prefeitura cuidasse mais do meio ambiente, beira de rios e córregos não tinha tanto pernilongo, se não tivesse tanto problema eles não viriam tanto, quando ta limpinho $e$ mais organizado os pernilongos diminuem, tem que cuidar do meio ambiente.

\section{EE. PARQUE ECOLÓGICO}

Sim, por causa da poluição, lixo e água acumulada, matagal, sujeira que tem nos rios e córregos. $O$ rio Tietê fica as vacas se a prefeitura cuidasse mais do meio ambiente, beira de rios e córregos não tinha tanto pernilongo, se não tivesse tanto problema eles não viriam tanto, quando ta limpinho e mais organizado os pernilongos diminuem, tem que cuidar do meio ambiente.

\section{EE. IRMÃ ANNETE}

Sim, falta de saneamento básico. Os problemas ambientais afetam a vida humana e a vida animal. Os pernilongos se acumulam em lugares de poluição: lixo, mato, muita sujeira, esgotos destampados a céu aberto, água acumulada nessas poças̀ que vai juntando poluição, gente que joga os excrementos, essas coisas direto no rio, os mosquitos, ratos gostam aí fica aquela coisa horrivel. 
Idéia Central C - Não desmatar, preservar o bairro e a natureza

\section{DSC}

\section{INTEGRAL}

Sim, as pessoas não preservam a natureza, não plantam, acabam com a cadeia ambiental deles. Tem que cuidar do bairro, não pode polvir se não aparecem os bichos: insetos, pernilongos, ratos, baratas etc.

\section{EE. PARQUE ECOLÓGICO}

Sim, as pessoas não preservam a natureza, não plantam. Tem que cuidar do bairro, não pode poluir se não aparecem os bichos: insetos, pernilongos, ratos, baratas etc.

\section{EE. IRMÃ ANNETE}

Por causa desse desmatamento, as pessoas acabam com a cadeia ambiental deles e eles vêm e infestam na casa da gente.

Idéia Central D - Poluição do ar e aquecimento global

\section{DSC}

\section{INTEGRAL}

Estamos vendo o aquecimento global do planeta, o calor tem se estendido de. manhã, de tarde, de noite né, tudo está asfaltado, as casas todas são azulejadas, as ruas todas estão asfaltadas. $O$ aquecimento faz eles se multiplicar. 


\section{EE. PARQUE ECOLÓGICO}

Tipo por causa do calor, aquecimento faz eles se multiplicar.

\section{EE. IRMÃ ANNETE}

Estamos vendo o aquecimento global do planeta, o calor tem se estendido de manhã, de tarde, de noite né, tudo está asfaltado, as casas todas são azulejadas, as ruas todas estão asfaltadas.

Idéia Central E - Acredita que não

\section{INTEGRAL}

Acho que não, não de pernilongos, ele faz parte da natureza.

\section{EE. PARQUE ECOLÓGICO}

Acho que não.

\section{EE. IRMÃ ANNETE}

Acho que não, tem problema ambiental que não tem nada a ver com pernilongo, ele faz parte da naturezá. 
Idéia Central F - Não sabe se há ássociação

\section{DSC}

\section{INTEGRAL}

Não saberia te responder, talvez não tenha ou tenha, não faço a mínima idéia.

\section{EE. PARQUE ECOLÓGICO}

Não sei, talvez não tenha ou tenha.

\section{EE. IRMÃ ANNETE}

Não saberia te responder, pode ser que sim, pode ser que não, não faço a mínima idéia.

Tabela 7. Distribuição do número e percentual de respostas compartilhadas pelos alunos por série das escolas Parque Ecológico e Irmã Annete sobre problemạs ambientais associados à reprodução de pernilongos, São Paulo, 2007

\begin{tabular}{|c|c|c|c|c|c|c|c|c|}
\hline \multirow[t]{2}{*}{ Idéias Centrais } & \multicolumn{2}{|c|}{$1^{2}$ ano } & \multicolumn{2}{|c|}{$2^{\circ}$ ano } & \multicolumn{2}{|c|}{$3^{9}$ ano } & \multicolumn{2}{|c|}{ Total } \\
\hline & $\mathrm{N}$ & $\%$ & $\mathrm{~N}$ & $\%$ & $N$ & $\%$ & $N$ & $\%$ \\
\hline $\begin{array}{l}\text { A - Acredita que šim, mas não explicou } \\
\text { a associação } \\
\text { B - Áquáneas }\end{array}$ & 25 & 30,49 & 12 & 23,08 & 12 & 20,00 & 49 & 25,26 \\
\hline $\begin{array}{l}\text { poluiçāo dos rios e córregos } \\
\text { C - Nāo desmatar, presenvar o bairro e }\end{array}$ & 35 & 42,68 & 18 & 34,62 & 31 & 51,67 & 84 & 43,30 \\
\hline a natureza & 3 & 3,66 & 6 & 11,54 & 0 & 0,00 & 9 & 4,64 \\
\hline $\begin{array}{l}\text { D - Poluição do ar e aquecimento global } \\
\text { E - Acredita que não }\end{array}$ & $\begin{array}{c}3 \\
15\end{array}$ & $\begin{array}{c}3,66 \\
18,29\end{array}$ & $\begin{array}{c}1 \\
11\end{array}$ & $\begin{array}{c}1,92 \\
21,15\end{array}$ & $\begin{array}{c}2 \\
11\end{array}$ & $\begin{array}{l}3,33 \\
18,33\end{array}$ & $\begin{array}{l}6 \\
37\end{array}$ & $\begin{array}{l}3,09 \\
19,07\end{array}$ \\
\hline F - Não sabe se há associação & 1 & 1,22 & 3 & 5,77 & 5 & 8,33 & 9 & 4,64 \\
\hline Total & 82 & 100,00 & 51 & 98,08 & 61 & $101,67^{*}$ & 194 & 100,00 \\
\hline
\end{tabular}

* Há variações nas frequiências, pois o mesmo indivíduo pode ter mais de uma idéia central para a mesma pergunta. 


\section{Discussão}

Primeira questão: como os pernilongos se criam (nascem)?

Referente à reprodução de mosquitos, as respostas produzidas pelos alunos relacionaram mais com a criação do mosquito ao ambiente em que se desenvolve, ou seja, a sua ecologia, observadas nas idéias centrais (tabela 3): G - Vegetação; B - Água poluída; A - Recipientes e lugares contendo água parada; E - Lixo; D - Lugares sujos; C - Lugares escuros. A idéia central F- nasce de outro pré-existente éstá relacionada ao ciclo biológico, sendo a terceira mais compartilhada entre os alunos no geral. Neste discurso observamos a fragmentação do conhecimento do ciclo reprodutivo do vetor. Das 58 respostas emitidas pelos alunos, sete $(12,07 \%)$ apontaram que os mosquitos nascem da mãe. Nesse discurso, afirmam que a fêmea coloca seus filhotes̉ na água, não descreveram o ovo e nem a larva, como se o insetos fossem animais vivíparos. Trinta e cinco $(60,34 \%)$ das respostas descreveram o ciclo reprodutivo dos mosquitos, citando principalmente a fase de ovo e posteriormente, a de larva, demonstrando assim, um importante conhecimento biológico sobre o ciclo reprodutivo dos mosquitos. Esse conhecimento é essencial para o controle dos vetores, uma vez que as pessoas podem eliminar os recipientes que servem para as fêmeas de algumas espécies depositarem seus ovos. Dezesseis $(27,59 \%)$ das respostas citaram apenas a fase de läva, fato preocupante, uma vez que, desconhecendo a fase de ovo, os indivíduos podem não entender as campanhas destinadas à eliminação dos ovos. 
Pesquisa realizada por Lefèvre e col. (2007) com moradores de São Sebastião, litoral norte do Estado de São Paulo, observaram que dentre as respostas, 13,21\% dos pesquisados não tinham conhecimento da fase de ovo no desenvolvimento do Aedes aegypti. Os autores relataram que, talvez, poucas pessoas soubessem da aderência do ovo à parede dos recipientes e, conseqüentemente, do transporte passivo do ovo.

A idéia central mais compartilhada entré os alunos foi a $\mathrm{G}$ - vegetação (tabela 3) que corresponde a $31,44 \%(n=61)$ das respostas dos alunos. Nesse discurso os alunos citaram que os pernilongos nascem no mato, capim, ou seja, na vegetação, provavelmente, devido à realidade dos moradores, que quando andam pela região através das gramíneas, deparam-se com inúmeros pernilongos adultos voando, o que lhes dá, talvez, a sensação de que os mosquitos nascem da vegetação, bem como o fato de que algumas campanhas de controle de mosquito do dengue privilegiarem o vetor alado através de desenhos do mesmo ẹm detrimento da fase de ovo.

Em 1996, o governo brasileiro lançou o Plano Nacional de Erradicação do Aedes aegypti privilegiando a erradicação do vetor em detrimento à educação e à participação da comunidade na eliminação dos criadouros (BRASSOLATTI \& ANDRADE 2002).

A campanha governamental de 1998, com o objetivo de conscientizar a população sobre a ameaça do vetor e das condições favoráveis a sua reprodução, divulgou a imagem de um inseto alado, amárelo com listras pretas, dentado, diferente das características reais do mosquito transmissor, uma das causas prováveis da não obtenção de resultados satisfatórios nas campanhas.

As idéias centrais relacionadas aos aspectos ecológicos de proliferação dos mosquitos demonstraram a ausência conhecimentos básicos sobre o ciclo de vida dos 
mosquitos: ovo, larva, pupa e adulto, bem como da necessidade de água para se reproduzirem. Essa falta de conhecimento pode dificultar o entendimento das campanhas baseadas no controle das larvas com a eliminação dos criadouros.

A idéia central B - água poluída (tabela 3) foi a segunda com maior intensidade entre os estudantes. Neste discurso oṣ alunos descreveram que os mosquitos nascem da água suja, poluída, nos córregos, lagoas, esgotos e rios.

Pesquisa realizada por Rosa (2004) demonstrou que os estudantes citaram a criação dos pernilongos através da água suja do rio, captando desta maneira, a realidade local mesmo na ausência do conhecimento científico. do problema, uma vez que as campanhas são baseadas na biologia e ecologia do Aedes aegypti, demonstraram, desta forma, conhecimento indireto sobre o Culex quinquefasciatus, mosquito bem domiciliado, frequiente e abundante na região, que constitui um fator de incômodo, por apresentar comportamento antropofílico, e procurar o homem, geralmente, no horário de repouso (CONSOLI \& LOURENÇO-DE-OLIVEIRA 1994). A constatação que os estudantes possuem esta informação é muito importante, uma vez que pode capacitá-los para o controle desse mosquito abundante na região.

Cinqüenta e sete $(29,38 \%)$ das respostas dos alunos, constituíram a idéia central A - Recipientes e lugares contendo água parada. Nesse discurso os alunos citaram a necessidade de água e dos diversos recipientes para a proliferação. ·

Trabalho desenvolvido por Claro (2004) e col. identificou os recipientes mais freqüentemente infestados por larvas de Aedes aegypti, entre eles, depósitos de água para consumo, vasos de plantas, pneus usados e latas que eram considerados pela maioria dos participantes como úteis para seu próprio uso. 
Pesquisa elaborada por Regis e col. (1996) em escola de Recife sobre controle integrado do vetor do agente etiológico da filariose com participação comunitária demonstrou que boa parte da população desconhecia o ciclo biológico do mosquito.

A idéia central mais compartilhada entre os alunos do $2^{\circ}$ ano foi a $\mathrm{F}$ - nasce de outro pré-existente (tabela 3). Provavelmente este fato possa estar relacionado ao conteúdo programático do ensino médio abordado nesta série - seres vivos: vírus, moneras, - protistas, fungos, plantas e animais (LOPES 2006a) e nas orientações dos Parâmetros Curriculares Nacionais - Ensino médio (MEC 1999). Na segunda série do ensino médio os alunos estudam as características gerais, anatomia e fisiologia dos nove filos de animais, entre eles, os artrópodes que englobam a classe dos insetos, sendo estudado o ciclo reprodutivo.

A idéia central mais compartilhada entre os alunos do $3^{\circ}$ ano foi a $\mathrm{B}$ - água poluída (tabela 3). Este fato, talvez possa estar relacionado ao conteúdo abordado nesta série - genética, evolução e ecologia (LOPES 2006b):

Os alunos estudam a poluição da atmosfera, poluição do ar; poluição da água e problemas ambientais, dentre eles, a poluição da águia e a proliferação de animais sinantrópicos.

A idéia central mais compartilhada entre os alunos do $1^{\circ}$ ano foi a $G$ - Vegetação (tabela 3). A idéia central F - nasce de outro pré-existente foi a segunda com maior intensidade entre os alunos, seguida pelas idéias centrais, B - Água poluída, A Recipientes e lugares contendo água parada, E - Lixo, respectivamente. 
As idéias centrais com maior intensidade entre os alunos das três séries do ensino médio foram: A - recipientes e lugares contendo água parada, B - água poluída, F - nasce de outro pré-existente e G - Vegetação (tabela 3).

Segunda questão: os pernilongos podem provocar problemas para as pessoas? Caso afirmativo. Quais?

Referente aos problemas provocados pelos mosquitos, a idéia central mais compartilhada pelos alunos das três séries foi a A - Provoca incômodo (tabela 4), formada por $46,91 \%$ das respostas emitidas. A idéia central D - Provoca dengue foi a segunda com maior intensidade entre os alunos do $1^{\circ} \mathrm{e} 2^{\circ}$ anos e a idéia central C (tabela 4) - provoca doença foi a segunda com maior intensidade entre os alunos do $3^{\circ}$ ano.

No discurso da idéia central A os alunos citaram as picadas que provocam alergias e o incômodo provocado na hora do repouso.

Pesquisa realizada por REGIS e col. (1996) numa comunidade em Recife, verificou que Culex quinquefasciatus se constituía um grande fator de incômodo para os habitantes da região devido as suas picadas e aos sons emitidos pelo vetor.

Culex quinquefásciatus tem tendência à álimentação com sangue humano (CONSOLI \& LOURENÇO-DE-OLIVEIRA 1994), o que permite seu desenvolvimento nas cidades, provocando intenso incômodo para as populações que vivem próximas aos seus criadouros (NATAL e col. 1991; ROSA 2004; TAIPE-LAGOS \& NATAL 2003), diminuindo a qualidade de vida (FORATTINI 2002). 
Em relação o dengue, $31,96 \%$ das respostas emitidas pelos alunos construíram a idéia central D - Provoca dengue, tendo grande intensidade entre os alunos das três séries (Tabela 4). Embora o relatório epidemiológico de' 18 de junho de 2008 tenha registrado apenas dois casos de dengue na região da subprefeitura de Ermelino Matarazzo (PMSP 2008c). Nesse discurso, os alunos citaram que os mosquitos provocam o dengue e discriminaram alguns sintomas.

A idéia central C (tabela 4) teve grande intensidade entre todos os alunos. Nesse discurso os estudantes não especificaram quais doenças podem ser transmissíveis por vetores.

Culex quinquefasciatus tem sido incriminado como potencial vetor do vírus da febre do Nilo Ocidental na transmissão de encefalites e meningites (NATAL \& UENO 2004; TURELL e col. 2001), que tem introdução iminente na América do Sul, devido às aves migratórias (LUNA e col. 2003).

As idéias centrais $\mathrm{E}$ e $\mathrm{F}$, os alunos citaram no seu discurso a transmissão da febre amarela, cujo agente etiológico é um vírus e da malária e leishmaniose, cujos agentes etiológicos são protozoários. Cento e noventa e quatro alunos foram entrevistados, mas não houve citação da filariose, doença citada nos livros de biologia do ensino médio e ilustrada com fotos de portadores da elefantíase; inclusive com o ciclo de transmissão da Wuchereria bancrofti (LOPES 2006a).

Para CONSOLI \& LOURENÇO-DE-OLIVEIRA (1994), Culex quinquefasciatus é o principal vetor do agente etiológico da filariose em alguns Estados do país. Tal capacidade decorre do seu comportamento de hábitos noturnos e elevada antropofilia (FORATTINI 1965). 
Segundo White (1989), Culex quinquefasciatus é vetor primário do agente etiológico da filariose em regiões da África, Ásia, América do Sul e do Pacífico. Larvas $\mathrm{L}_{3}$ de Wuchereria bancrofti, agente etiológico da filariose linfática foram encontradas em fêmeas dessa espécie em pesquisas realizadas por Medeiros e col. (1992), nas cidades de Recife-PE, Olinda-PE e Jaboatão-PE e em Maceió-AL (CALHEIROS 1996).

Terceira questão: o que pode ser feito para acabar com os pernilongos?

Referente ao controle de mosquitos as três idéias centrais (tabela 5) com maiores intensidades entre os alunos das três séries foram: idéia central A - Usar inseticidas; BNão acumular água; C - Não acumular lixo. A idéia central A foi construída com $51,03 \%$ (tabela 5) das respostas emitidas pelos alunos. Nesse discurso os estudantes citaram o uso intenso de spray, pastilhas etc. e a da pulverizaçãb de inseticidas no bairro. Alguns explicaram que fecham as janelas da residência para usar o inseticida e provavelmente, desconhecem os perigos associados a esta prática.

O programa para Pesquisas em Doenças Tropicais da Organização Mundial de Saúde fomentou e apoiou, nas últimas décadas, pesquisas de desenvolvimento de metodologias de controle de vetores que sejam mais seguras que os pesticidas químicos (WHO 1995). O controle químico de mosquitos tem sido em geral associado a problemas como agressão ao ambiente, agressão à saúde da população e desenvolvimento de resistência (GUBLER 1989). Tem sido um dos métodos mais usados como parte de ação de manejo sustentável e integrado para os mosquitos em 
saúde pública (ROSE 2001), ainda muito utilizado no controle do Culex quinquefasciatus.

O controle da população de vetores nas últimas décadas tem enfrentado problemas, como por exemplo: resistência aos inseticidas químicos e às toxinas de origem biológica; desequilíbrio ambiental com o envenenamento do ecossistema, que favorece algumas espécies em detrimento de outras; falta de continuidade das campanhas anteriores; aumento das doenças reemergentes (BRANCO 1983; RIBEIRO 2004; SMA 2002).

Estudo realizado em Porto Rico (GUBLER 1989) através da nebulização de inseticidas para o controle de mosquitos adultos mostrou-se de baixa eficácia.

A eliminação ou redução dos criadouros do Aedes aegypti ṇão livra a comunidade pesquisada do Culex quinquefasciatus, fator esse que provavelmente justifica a idéia central $\mathrm{A}$ - Usar inseticidas como sendo a primeira mais compartilhada entre os àlunos.

A idéia central B - Não acumular água e C - Não acumular lixo (tabela 5) foram respectivamente, a segunda e a terceira idéia com maior intensidade entre os alunos. Provavelmente em função da campanha contra o dengue, que solicita à população inúmeros cuidados especiais com o lixo e com todos os recipientes que possam acumular água e servir de criadouros para os mosquitos.

No discurso da idéia B os alunos citaram que não devem·deixar água parada, tomar cuidado com pneus, garrafas, plantas, baldes, latas etc. e fazer a parte que cabe a cada um como é dito na televisão. 
Pesquisa realizada por REGIS e col. (1996), em Recife sobre controle integrado do vetor da Wuchereria bancrofti responsável pela filariose, revelou que a maioria dos entrevistados apontou água suja e lixo como locais de reprodução de mosquito. Cerça de $17 \%$ dos entrevistados informaram desenvolverem ações para acabar os focos de proliferação dos mosquitos. Apenas $10 \%$ usam inseticidas em suas residências. Mosquiteiros e ventiladores são os meios mais usados para se proteger das picadas.

No discurso $\mathrm{C}$ os alunos falaram sobre a importância de não acumular lixo e manter tudo nos devidos lugares.

Pesquisa realizada em Salvador, no Estado da Bahia, identificou ausência de coleta de lixo em $44 \%$ das residências, conduzindo parte da população, principalmente da periferia urbana, a depositar os resíduos domiciliares em córregos, encostas e pontos de lixo (BARRETO 1999), favorecendo a proliferação de certas espécies de mosquitos.

No discurso D - Limpar a vegetação citaram a necessidade de redução das gramíneas para controlar a proliferação de mosquitos, provavelmente, pela grande quantidade de pernilongos adultos se encontrarem entre os vegetais da região.

No discurso E - Ter consciência da situação os alunos citaram a importância da responsabilidade ambiental e social.

No discurso H - Canalizar rios e esgotos os alunos citaram a canalização do rio, que embora possa resolver parcialmente os problemas relacionados a animais sinantrópicos, não é o caminho mais certo; os córregos e rios têm que ser tratados e. recuperados para permitirem o desenvolvimento da.vida aquática, contribuindo para o equilíbrio dos ecossistemas, fornecendo alimento e opções de lazer. 
No discurso $\mathbf{J}$ - O governo atuar os alunos citaram a importância da atuação do governo para amenizar os problemas ambientais.

Os impactos negativos das degradações ambientais resultam principalmente da ausência de políticas públicas, da precariedade dos serviços prestados e da omissão do poder público, porém, é também do descaso e da omissão dos próprios habitantes dos bairros mais carentes de infra-estrutura, onde na maioria das vezes, os moradores não possuem acesso a educação e saúde pública de qualidade.

Quarta questão: na sua casa os pernilongos costumam picar as pessoas durante o dia ou durante a noite?

Referente ao período de hematofagia dos mosquitos a tabela 6 demonstra que a idéia central $\mathrm{A}$ - durante a noite foi a mais compartilhada entre os alunos das três séries do ensino médio. Nesse discurso os alunos relataram que o mosquito pica à noite, continuando pela madrugada até amanhecer.

As escolas pesquisadas estão próximas ao Rio Tietê. Os bairros que os alunos residem carecem de infra-estrutura de saneamento do meio, favorecendo desta forma, a proliferação de animais sinantrópicos, entre eles, diversas espécies de vetores. A principal espécie de mosquito dentro das casas dos estudantes entrevistados é provavelmente, o Culex quinquefasciatus, mosquito abundante na região estudada e obrigatoriamente de hábito noturno (CONSOLI \& LOURENÇO-DE-OLIVEIRA 1994; NATAL e col. 1991; ROSA 2004). 
A falta de envolvimento da população nas campanhas, talvez seja em função da ausência de argumentos convincentes e meios adequados para a eliminação de criadouros, durante as campanhas de combate à dengue (BRASSOLATTI \& ANDRADE 2002). O mosquito predominante na área pesquisada é o Culex quinquefasciatus que possui nicho ecológico diferente do Aedes aegypti, fato que pode desestimular os moradores a acatarem as informações veiculadas pela mídia, uma vez que elas são destinadas ao controle de Aedes aegypti.

Culex quinquefasciatus e Aedes aegypti são mosquitos freqüentes dentro e nas vizinhas das casas no Brasil. O primeiro pratica hematofagia à noite, seus ovos são colocados em "jangadas" diretamente sobre a água poluída e turva. Já 'as fêmeas de Aedes aegypti praticam hematofagia durante o dia, depositam seus ovos, individualmente, fora dos criadouros formados ou não, em locais úmidos que o nível de água clara e limpa antigirá no futuro (CONSOLI \& LOURENÇO-DE-OLIVEIRA 1994).

A categoria mais compartilhada na segunda questão entre os alunos das três séries foi a idéia central A - Provoca incômodo (Tabela 4) que está associada à idéia central A - durante a noite (Tabela 6) da quarta questão, que teve a maior intensidade entre os alunos, corroborando a predominância do Culex quinquefasciatus dentro das residências, o que diminui a qualidade de vida (FORATTINI 2002), justificando desta maneira, a extrema importância do seu controle.

A idéia central B - durante o dia e a noite (tabela 6) foi a segunda mais compartilhada entre os alunos. Nesse discurso os alunos citaram que ocorre hematofagia durante o dia e a noite, correspondendo a $9,28 \%(n=18)$ das respostas dos alunos do 
ensino médio (tabela 6), o que pode indicar pouca atividade de espécies de mosquitos de hábitos diurnos.

A idéia central $\mathrm{C}$ - durante o dia (tabela 6 ) foi a terceira mais compartilha pelos alunos, tendo um baixo poder de penetração entre os estudantes, corroborando desta maneira, a informação anterior, nesse discurso os alunos citaram que o mosquito aparece durante o dia, sendo responsável pela transmissão do vírus da dengue:

Quinta questão: você acha que alguns problemas ambientais estão relacionados à criação de pernilongos? De que maneira?

Referente aos problemas àmbientais e proliferação de mosquitos, a idéia central mais compartilhada pelos alunos das três séries foi a B - Água acumulada, lixo, gramíneas, poluição dos rios e córregos (tabela 7), correspondendo a 43,30\% ( $\mathrm{N}=84)$. Nesse discurso, os alunos citaram que a poluição, o lixo, os córregos e rios abandonados estão relacionados com a proliferação de mosquitos.

A exacerbada produção de embalagens e produtos descartáveis provoca o acúmulo do lixo, podendo liberar odor desagradável e intensificar proliferação de mosquitos (FORATTINI 1998; GÜNTHER 2000; TAUIL 2002).

A população tem adotado modelos de consumo exagerado de produtos acondicionados em recipientes de plâstico, alumínio, vidro, dentre outros, mas, como não tem a prática da reciclagem, aumentam a produção de lixo e de criadouros potenciais. 
A distribuição injusta dos níveis de renda, resulta em populações cada vez maiores vivendo em regiões onde abastecimento de água, coleta de lixo e esgotamento sanitário são precários ou inexistentes (TAUIL 2001).

A idéia central A - Acredita que sim, mas não explicou a associação (tabela 7) foi a segunda idéia mais compartilhada pelos estudantes, correspondendo a $25,26 \%(\mathrm{~N}=$ 49). Nesse discurso os alunos citaram a relação, mas não especificaram.

A péssima infra-estrutura de habitação, de coleta de lixo e de abastecimento de água em áreas urbanas está entre as principais causas a reemergência de doenças provocadas por agentes etiológicos transmissíveis por vetores, entre elas, o dengue. Os resíduos sólidos urbanos que constituem uma preocupação ambiental, principalmente na periferia das metrópoles de países subdesenvolvidos, resultam em agravos à saúde e degradação ambiental (REGO e col. 2002).

Pesquisa realizada por Santos (2001) sobre saúde e educação ambiental cọm professores em Vargem Grande Paulista diagnosticou em todas as questões abordadas o lixo como problema que afeta a cidade, o Estado, o país e o planeta. A maioria dos entrevistados tinha uma visão naturalista sobre o ambiente, desconsiderando o homem e os fatores sociais.

A idéia central E - Acredita que não (tabela 7) foi a terceira mais compartilhada pelos alunos, $19,07 \%(\mathrm{~N}=37)$ das respostas obtidas, fato preocupante. Nesse discurso os alunos citaram que não há relação entre problemas ambientais e proliferação de mosquitos.

A idéia central C - Não desmatar, preservar o bairro e a natureza (tabela 7) foi a quarta mais compartilhada entre os alunos do $1^{\circ}$ ano e $2^{\circ}$ ano, não sendo compartilhada 
entre os alunos do $3^{\circ}$ ano. Nesse discurso os alunos citaram a importância da preservação ambiental no controle dos mosquitos.

Pesquisa realizada por PELICIONI (1998) com alunos do ensino fundamental sobre exemplos de problemas ambientais teve como os mais citados: o desmatamento/queimadas/falta de árvores $(72,3 \%)$, lixo/sujeira $(48,2 \%)$, poluição do ar $(48,2 \%)^{\circ}$, poluição das águas $(43,4 \%)$. Confundiram problemas ambientais com problemas sócio-econômicos $(27,7 \%)$. Quanto à relação entre doenças e problemas ambientais, mais de $90 \%$ identificaram o dengue e o cólera; $68,7 \%$ a leptospirose; e $62,6 \%$ as verminoses. Equivocadamente doenças que não têm relação de causalidade com condições ambientais foram citadas com porcentagem relativamente alta, como por exemplo: reumatismo e diabetes. $\mathrm{O}$ povo foi apontado como o maior responsável pelo surgimento de problemas ambientais.

A idéia central D - Poluição e aquecimento do global (tabela 7) teve um baixo poder de penetração entre os alunos das três séries. Nesse dișcurso, relacionaram o aquecimento global com a proliferação de mosquitos.

O aumento global da temperatura favorece a reprodução de diversas espécies em detrimento de outras e entre as favorecidas estão os vetores. Em 1896, o químico sueco Svante August Arrhenius afirmou que o uso demasiado do carvão como combustível elevaria a temperatura mundial, o que èstá aparentemente ocorrendo. 


\section{Conclusões}

1. As representações sociais sobre reprodução demonstraram que houve fragmentação da aprendizagem em relação ao ciclo biológico e os aspectos ecológicos do mosquito, fato que pode comprometer as campanhas de controle dos vetores.

2. As representações sociais sobre problemas provocados por vetores demonstraram o intenso incômodo causado pelos mosquitos na região e o pequeno grau de conhecimento assimilado sobre a transmissão de agentes etiológicos responsáveis por algumas doenças, como a dengue e a febre amarela e a apreensão inadequada de outras, como por exemplo, AIDS e gripe.

3. As representações sociais sobre controle demonstraram o uso intenso de inseticidas para combater o vetor e os cuidados que devem ser tomados com recipientes que acumulam água em detrimento do saneamento do meio.

4. As representações sociais sobre as espécies mais comuns nas casas indicaram a presença provável de Culex quinquefasciatus, uma vez que, a idéia central mais compartilhada na quarta questão fọi a idéia central A - durante a noite que corresponde a $85,57 \%(n=166)$ das respostas dos alunos. Já na segunda questão 
a idéia mais compartilhada entre os alunos das três séries foi a idéia central A Provoca incômodo, corroborando desta forma, com a predominância do Culex quinquefasciatus dentro das residências.

5. As representações sociais sobre os problemas ambientais associados com proliferação de mosquitos demonstraram certo grau de conhecimento satisfatório em relação à poluição do ambiente aquático, poluição do ambiente terrestre e a reprodução dos vetores, o que pode ser melhor controlado com saneamento do meio.

A educação é a solução para maioria dos problemas que permeiam as sociedades atuais. Nas últimas décadas inúmeros países desenvolveram métodos para o aprimoramento dos seus sistemas educativos. È notável a debilidade do ensino médio público em muitas escolas do Brasil. Urge a necessidade de uma escola de qualidade para formação de cidadãos críticos que possam contribuir para amenizar as desigualdades sociais. 


\section{Recomendações}

- Desenvolver projetos pédagógicos utilizando como subsídios os resultados gerados pela pesquisa.

- Dialogar com os alunos sobre a necessidade de amplas medidas sanitárias ambientais para o controle dos vetores.

- Desenvolver projetos nas unidades escolares de educação ambiental com a implementação da Agenda 21

- Informar os alunos sobre os vetores de valor epidemiológico que habitám a região, visando ao desenvolvimento de campanhas alternativas mais eficazes no controle dos mesmos.

- Realizar palestras, seminários e debates, a fim de que possam compreender melhor as questões que envolvem problemas ambientais, a proliferaçāo e o controle de culicídeos.

- Reivindicar às entidades responsáveis pelo controle de culicídeos, medidas que visem o manejo integrado dos mosquitos.

- Esclarecer os agravos à saúde relacionados ao uso de inseticidas residenciais.

- Informar os alunos sobre a importância do uso de telas para as janelas e portas das casas para limitar o acésso de culícideos.

- Explicar para os alunos as complexas relações existentes entre problemas ambientais e proliferação de animais sinantrópicos. 


\section{Referências Bibliográficas}

Abric JC. A abordagem estrutural das representações sociais. In: Moreira ASP, Oliveira DC, organizadoras. Estudos interdisciplinares de representação social. Goiânia: AB; 1998. p. 27 e 38.

Barreto ML. Avaliação do impacto epidemiológico do programa de saneamento ambiental da Baía de Todos os Santos (Bahia Azul), 9 Relatório quadrimestral; 1999. Salvador: Secretaria de recursos hídricos saneamento e habitação/Instituto de saúde coletiva, Universidade Federal da Bahia.

Borges FG. Valorização econômica do meio ambiente: o caso da B. Guarapiranga-SP. In: Veiga JE da, organizador. Ciência ambiental primeiros mestrados 1998. São Paulo: Annablume/FAPESP; 1998. p324.

Branco SM. Poluição: a morte de nossos rios. $2^{\circ}$ ed. São Paulo: ASCETESB; 1983.

Bracco JE. Avaliação da resistência a inseticidas em população de Culex quinquéfasciatus (diptera: Culicidae) do Rio Pinheiros (São Paulo, Brasil). São Paulo; 1998. [Dissertação de Mestrado da Faculdade de Saúde Pública da USP].

Brassolatti RC \& Andrade CFS. Ávaliação de uma intervenção educativa na prevenção da dengue. Ciência \& Saúde Coletiva 2002; 7(2): 243-251.

Calheiros CML. Transmissores em potencial e naturalmente infectados pela Wuchereria bancrofti (Cobbold, 1877) em Maceió - Alagoas [Dissertação de Mestrado]. Belo Horizonte: Departamento de Parasitologia do ICB/UFMG; 1996 
CDC-Center for Disease Control and Prevention. Biology and control of Aedes aegypti. Atlanta, 1979.

CDC-Center for Disease Control and Prevention. Recommendations of the International Task Force for disease eradication. MMWR 1993; 2(RR-16):1-38.

Claro LBL, Tomassini HCB, Rosa MLG. Prevenção e controle do dengue: uma revisãe de estudos sobre conhecimentos, crenças e práticas da população. Cad. Saúde Pública 2004; 20(6): 1447-1457.

Consoli RAGB \& Lourenço-de-Oliveira R. Principais mosquitos de importância sanitária no Brasil. Rio de Janeiro: FIOCRUZ; 1994.

Constituição (1988). Constituição da República Federativa do Brasil. Brasília, DF: Senado; 1988.

Coosemans M \& Mouchet J. Consequences of rural' development on vectores and their seu controle. An. Soc. Belge. Med. Trop. 1990;70:5-23.

Chiaravalloti NF. 1993. Aedes aegypti na Região de São José do Rio Preto, Estado de São Paulo. São Paulo; 1993. [Dissertação de Mestrado - Faculdade de Saúde Pública da USP].

Dias GF. Educação Ambiental: princípios e práticas. 8ª ed. São Paulo: Gaia; 2003.

Diegues ACS. Desenvolvimento sustentável ou sociedades sustentáveis: da crítica dos modelos aos novos paradigmas. São Paulo Perspec; 1992; 6 (1/2): 22-9. 
Dixon WJ \& Massey Jr.F. Introduction to Statistical Analisys. $2^{\mathbf{a}}$ ed. New York, McGrawhill; 1957.

Farr RM. Representações sọciais: a teoria e sua história. In: Guareschi, P. e Jovchelovitch, S., organizadores. Textos em representações sociais. $2^{\circ}$ ed. Petrópolis: Vozes; 1995. p. 31-59.

Ferreira ABH. Dicionário Aurélio básico da língua portuguesa. São Paulo: Nova Fronteira; 1998.

Freitas CM, Porto MFS, Moreira JC, Pivetta F, Machado JMH, Freitas NBB, Arcuri AS. Segurança química, saúde e ambiente: perspectivas para a governança no contexto brasileiro. Cad. Saúde Pública 2002; 18(1):249-256.

Forattini OP. Entomologia Médica. São Paulo: EDUSP; 1965.

Forattini OP. Mosquitos Culicidae como vetores emergentes de infecções. Rev Saúde Pública 1998; 32(6): 497-502.

Forattini OP. Espécie de Culex (Culex), p. 693-722. In Forattini OP. Culicidologia Médica - v.2. São Paulo: EDUSP; 2002. 860 p.

Forattini OP. Ishiata GK, Rabello Ex, Cotrim MD. Observação sobre os mosquitos Culex da cidade de São Paulo, Brasil. Rev Saúde Pública. 1973; 7: 315-330.

Forattini OP, Kakitani I, Massad E, Marucci D. Studies on mosquitoes (Díptera: Culicidae) and anthropic environment. 4-Survey of resting adults and synanthropic behavior in South-Eastern, Brazil. Rev Saúde Pública. 1993; 27 : 398-411. 
Forattini OP, Marques GRAM, Kakitani I, Brito M, Sallum M. Significado epidemiológico dos criadouros de Aedes albopictus em bromélias. Rev Saúde Pública 1998; 32(2): 186-188.

FUNASA-Fundação Nacional de Saúde. Relatório da reunião de Avaliação do Programa de Controle da Filariose Linfática, referente ao Plano de Eliminação da Filariose Linfática no Brasil, Recife-PE, 2000. Brasília, 2000.

Gil AC. Métodos e técnicas em pesquisa social. São Paulo, Ed. Atlas; 1991

Gomes AC, Forattini OP. Resting places of mosquitoes Culex (Culex) in rural zones (Diptera: Culicidae).Rev Saúde Pública 1990; 24(5): 394-397.

Google Maps Brasil. [acesso em 05 nov 2008]. Disponível em: http://maps.google.com.br/maps?hl=pt-BR\&tab=wl

Gubler DJ. Aedes aegypti and Aedes albopictus-borne disease control in the 1990's: top down or bottom up. Am J Trop Med Hyg 1989; 40: 571-578.

Günther WMR. Minimização de resíduos e educação ambiental. In: VII Seminário de Resíduos Sólidos e Limpeza Pública; 2000 abr 3-7; Curitiba, (BR). São Paulo: Associação Brasileira de Limpeza Pública; 2000.

Herculano SC. Do desenvolvimento (in)suportável à sociedade infeliz. In: Goldemberg M, coordenadora. Ecologia, ciência e política. Rio de Janeiro: Ed. Revan; 1992. p. 9-48. 
Kendall C, Hudelson P, Leontsini E, Winch P, Lloyd L. Urbanization, dengue and the health transition: anthropological contributions to international health. Medical Anthropology Quarterly 1991; 53: 257-268.

Laporta GZ, Urbinatti PR, Natal D. Aspectos ecológicos da população de Culex quinquefasciatus Say (Diptera, Culicidae) em abrigos situados no Parque Ecológico do Tietê, São Paulo, SP. Rev. Bras. entomol 2006; 50(1): 125-127.

Lefèvre AMC, Ribeiro AF, Marques GRAM, Serpa LLN, Fernando L. Representações sobre dengue, seu vetor e ações de controle por moradores do município de São Sebastião, litoral Norte do Estado de São Paulo, Brasil. Cad. Saúde Pública 2007; 23(7): 1696-1706.

Lefèvre F, Lefèvre ACM. O discurso do sujeito coletivo: Um novo enfoque em pesquisa qualitativa. Caxias do Sul: EDUCS; 2003.

Lefèvre F, Lefèvre AMC. O sujeito coletivo que fala. Interface (Botucatu) 2006; 10 (20): 517-524.

Legislação do Meio Ambiente 1996: atos internacionais e normas federais. $3^{a}$ ed. Brasília: Senado Federal, Subsecretarias de Edições Técnicas, 1996.

Lenzi MF, Camillo-Coura L, Grault CE, Val MB. Estudo do dengue em área urbana favelizada do Rio de Janeiro: considerações iniciais. Cad. Saúde Pública 2000; 16(3): 851-856.

Lopes SGBC, Mendonça VL. Biologia: Introdução ao estudo dos seres vivos. São Paulo: Saraiva, 2006a. v.2. 
Lopes SGBC, Mendonça VL. Biologia: Introdução ao estudo dos seres vivos. São Paulo: Saraiva, 2006b. v.3.

Luna EJA, Pereira LE, Souza RP. Encefalite do Nilo Ocidental, nossa próxima epidemia? Epidemiologia e Serviços de Saúde 2003; 12 (1): 7-19.

Mattos D, Mota S, Dreyer G. Aspectos da realidade social de crianças e adolescentes atendidos em serviço de referência para filariose bancroftiana, Recife, estado de Pernambuco. Rev. Soc. Bras. Med. Trop. 2008; 41(1): 29-35.

McCormick J. Rumo ao Paraíso: a história do movimento ambientalista. Rio de Janeiro, Relume-Dumará; 1992.

Medeiros Z, Dreyer G, Andrade L, Pires ML, MendesJ, Pimentel R. Wuchereria bancrefti microfilarialdensity of authochthonous cases and natural Culex infectivity rates in Northeast Brazil. Journal of Tropical Medicine and Hygiene 1992; 95:214-217.

Michelat G. Sobre a utilização da entrevista não diretiva em Sociologia. In: Thiollente, (Machado, 1995) JM. Crítica Metodológica, Investigação Social e Enquete Operária. Col. Teoria e História 6. Sẳo Paulo: Polis; 1985. p194

MEC - Ministério da Educação. Parâmetros Curriculares Nacionais - Temas Transversais: ensino de $5^{\mathrm{a}}$ a $8^{\mathrm{a}}$ séries. Brasília: Secretaria de Ensino Fundamental, 1998.

MEC - Ministério da Educação. Parâmetros Curriculares Nacionais - Temas Transversais: 'ensino médio. Brasília: Secretaria da Educação Média e Tecnológica. Brasília: Ministério da Educação, 1999. 
Minayo MCS. O desafio do conhecimento: pesquisa qualitativa em saúde. $78^{a}$ ed. São Paulo: Hucitec; RJ: Abrasco; 2000.

Minayo MCS. Saúde e ambiente no processo de desenvolvimento. Ciênc. SaúdeColetiva $1988 ; 3(2): 4-5,1998$.

Minayo MCS. O conceito de representações sociais dentro da sociologia clássica. In: Guareschi, P. e Jovchelovitch, S., organizadores. Textos em representações sociais. Petrópolis: Vozes; 1995. p.89-111.

MMA - Ministério do Meio Ambiente. Lei n 9.795, de 27 de abril de 1999. Dispõe sobre a Educação. Ambiental, institui a Política da Educação Ambiental e dá outras provjidências. Disponível em: http://www.mma.gov.br/sitio/index.php?ido=conteudo. monta\&idEstrutura=20\&idConteudo=967> Acesso 05jan 2009

Moscovici S. A representação social da psicanálise. Rio de Janeiro: Zahar; 1978.

Moscovici S. Prefácio. In: Guareschi P. et al. Textos em representações sociais. Petrópolis: Vozes; 1995. p.11.

Motta M \& Teixeira F. Conhecendo alguns modelos mentais infantis sobre Filariose Linfática. Ciênc. educ. (Bauru) 2007 v. 13, n. 3: 323-336.

Natal D, Paganelli CH, Santos JLF. Composição da população adulta de Culex (Culex) quinquefasciatus Say, 1823 em ecótopos próximos à represa Edgard de Souza, no município de Santana de Parnaíba, Estado de São Paulo, Brasil. Rev Brasileira Entomologia 1991; 35(3): 539-543 
Natal D, Barata EAMF, Urbinatti PR, Barata JMS. Contribuição ao conhecimento da fauna de imaturos de mosquitos (Diptera, Culicidae) em área de implantação da hidroelétrica na bacia do Rio Paraná, Brasil. Rev Brás Entomol 1995; 39: 897-899.

Natal D \& Ueno HM. Vírus do Nilo Ocidental: características da transmissão e implicações vetoras. Ver Entomol. Vect. 2004; 11(3): 417-433.

O'Meara GF, Gettman AD, Evans LFJr, GA Curtis. The spread of Aedes albopictus in Florida. American Entomologist 1993; 39(3): 163-172.

O’Meara GF, Evans LFJr, Womack ML. Colonization of rock holes by Aedes albopictus in the southeastern United States. J Am Mosq Control Assoc 1997; 13(3): 270-274.

Oliveira MSBS. Representações sociais e sociedades: a contribuição de Serge Moscovici. Rev. bras. Ci. Soc. 2004, vol 19, n. 55, p. 180-186.

Oliveira RM. A dengue no Rio de Janeiro: repensando a participação popular em saúde. Cad Saúde Pública 1998; 14 (supl.2): 69-78.

OMS (Organización Mundial de la Salud). Resistencia de los vectores y reservorios de enfermedades a los plaguicidas. $10^{\circ}$ Informe del Comité de Expertos de la OMS en biologia de los vectores y lucha antivectorial; Genebra: OMS, Tec Rep Ser 737, 1986

OPS (Organização Panamericana de Saúde). Diretrizes Relativas à prevenção e ao Controle do Dengue Hemorrágico nas Américas. Washington: Organização Panamericana de Saúde, 1991

Panpana E. A textbook of malaria eradication. London: Oxford University Press; 1963. 
Pelicioni AF. Educação Ambiental Limites e Possibilidades de uma Ação Transformadora. São Paulo; 2002 [Tese de Doutorado - Faculdade de Saúde Pública da USP].

Pelicioni AF. Educação Ambiental na Escola: Um levantamento das percepções e práticas de estudantes de primeiro grau a respeito de meio ambiente e problemas ambientais. São Paulo; 1998. [Dissertação de Mestrado - Faculdade de Saúde Pública da USP].

Pereira M. Produtividade e habitats larvários de Aedes aegypti em Santos, Estado de São Paulo. São Paulo; 2001. [Tese de Doutorado da Faculdade de Saúde Pública dá USP].

Philippi A \& Pelicioni MC. Visão de Interdisciplinaridade na Educação Ambiental. In: Philippi A \& Pelicioni MC. Educação Ambiental. Desenvolvimento de Cursos e Projetos. São Paulo: Sigmus; 2000.

PMSP. Prefeitura Municipal de São Paulo. Dados' Demográficos dos Distritos pertencentes as Subprefeituras. [acesso em 04 nov 2008a]. Disponível em: http://portal.prefeitura.sp.gov.br/secretarias/subprefeituras/subprefeituras/dados/0002

PMSP. Prefeitura Municipal de São Paulo. Dados Demográficos dos Distritos pertencentés as Subprefeituras. [acesso em 05 nov 2008b]. Disponível em: http://portal.prefeitura.sp.gov.br/subprefeituras/spem/dados/aspectos_demograficos/000 4

PMSP. Prefeitura Municipal de São Paulo. Dados Demográficos dos Distritos pertencentes as Subprefeituras. [acesso em 06 nov 2008c]. Disponível em: http://portal.prefeitura.sp.gov.br/noticias/sec/saude/2008/06/0009 
Regis L, Furtado AF, Oliveira CMF, Bezerra CB, Silva LRF, Araújo J e col. Controle integrado do vetor da filariose com participação comunitária, em área urbana no Recife, Brasil. Cad Saúde Pública 1996; 12(4):473-482.

Rego RCF, Barreto ML, Killinger CL. O que é lixo afinal? Como pensam mulheres residentes na periferia de um grande centro urbano. Cad. Saúde Pública 2002; 18(6): 1583-1592.

Ribeiro H. Saúde Pública e meio ambiente: evolução do conhecimento e da prática, alguns aspectos éticos. Saude soc. 2004; 13(1): 70-80.

Rodrigues VR. Coordenadora. Muda o mundo, Raimundo! Educação ambiental no ensino básico do Brasil, Brasília (DF), Fundo Mundial para a Natureza - WWF; 1996.

Rosa, JC. Educação na Escola: conhecimento dos alunos a respeito de mosquitos (Diptera: Culicidae) e problemas ambientais. São Paulo; 2004. [Dissertação de Mestrado - Faculdade de Saúde Pública da USP].

Rose RI. Pesticides and public health: methods management. Emerg. Infec.Dis. $2001 ; 7(1): 17-23$.

Rozendaal JA. Vector control methods for use by individuals and comnunities. Genebra: World Health Organization. 1997.

Santos JVK. Saúde e Educação Ambiental em Vargẹm Grande Paulista. São Paulo, 2001. [Dissertação de Mestrado - Faculdade de Saúde Pública da USP]. 
Sato M. Educação Ambiental. São Paulo: RIMA; 2002

SMA - Secretaria do Meio Ambiente do Estado de São Paulo - Coordenadoria de Educação Ambiental. Educação Ambiental e desenvolvimento: documentos oficiais. São Paulo, 1994. (Série Documentos).

SMA - Secretaria do meio ambiente do Estado de São Paulo. O Rio Pinheiros. Centro de Editoração da Secretaria do Meio Ambiente do Estado de São Paulo. São Paulo, 96p. 2002.

Seghal SS, Pillai MK. Preliminary studies on the chemical nature of mosquito-breeding waters in Delhi. Bull World. Health Organ. 1970; 42(4): 647-650.

Simioni AMC, Lefèvre F, Bicudo Pereira IMT. Metodologia Qualitativa nas Pesquisas em Saúde Coletiva: considerações teóricas e instrumentais. São Paulo; 1997. (Série Monográfica do Departamento de Prática de Saúde Pública da FSP, 2).

Sorrentino M. Educação Ambiental e Universidade: um estudo de caso. São Paulo, 1995. [Tese de Doutoramento - Faculdade de Saúde Pública da USP].

Taipe-Lagos CB \& Natal D. Abundância de culicídeos em área metropolitana preservada è suas implicações epidemiológicas. Rev Saúde Pública 2003; 37(3):275279.

Tauil PL. Urbanização e ecologia do dengue. Cad. Saúde Pública 2001; 17(Suplemento):99-102. 
Tauil PL. Aspectos críticos do controle do dengue no Brasil. Cad Saúde Pública 2002; 18(3): 867-871.

Turell MJ, Sardelis MR, Dohm DJ, O'guim ML. Potential North American vectors of West Nile Virus. Annual New York Academy Sciensę 2001; 951: 317-324

Urbinatti PR, Sendacz S, Natal D. Imaturos de mosquitos (Diptera: Culicidae) em parque de área metropolitana aberto à visitação pública. Rev de Saúde Pública 2001; 35: 461-466.

Vítor Neto, JB. Revisão dos métodos de controle e dos mecanismos de resistência do Culex quinquefasciatus (Díptera: Culicidae). São Paulo; 2006. [Dissertação de Mestrado - Faculdade de Saúde Pública da USP].

Wagner W. Sócio-gênesé e características das representações sociais. In: Moreira ASP, Oliveira DC, organizadoras. Estudos interdisciplinares de representação social. Goiânia: AB; 1998. p. 3 e 25.

White GB. Geografical Distribution of Arthropod-borne Diseases and their Principal Vectors. Geneva: World Health Organization; 1989. Lymphatic filariasis, p.23-24.

World Health Organization. Chemical methods for the control of vectores and pest of public health importance. Chavesse DC \& Yap HH Eds., WHO/CDT/WHOPES. Geneva, 1987.

World Health Organization. Lymphatic filariasis infection \& disease: control strategies. In: Report of a Consultative Meeting held at the University Sains Malaysia Penang 1994; Malaysia; 1994. Geneva: WHO; 1994. 
World Health Organization. Bridging the Gaps. World Health Report, Geneva, 1995.

World Health Organization. Special programme for research and training in tropical disease. Geneva; 1995. (WHO - Twelfth Programme Report of the UNDP/World Bank).

World Health Organization. Global programme to eliminate lymphatic filariasis. Weekly Epidemiological Record 80: 202-212, 2005.

Yadav RS, Sharma VP, Chand SK. Mosquito Breeding and Resting in Treeholes in Forest Ecosystem in Orissa Indian Journal of Malariology 1997; 34: 8-16. 


\section{Anexo I}

\section{Roteiro}

Nome:

Série:

Bairro onde mora:

Sexo: ( ) masculino ( ) feminino.

Data de nascimento:

\section{Entrevista}

1. Como os pernilongos se criam (nascem)?

2. Os pernilongos podem provocar problemas para as pessoas? Caso afirmativo. Quais?

3. O que pode ser feito para acabar com os pernilongos?

4. Na sua casa os pernilongos costumam picar as pessoas durante o dia ou durante a noite?

5. Você acha que alguns problemas ambientais estão relacionados à criação de pernilongos? De que maneira? 


\section{Anexo II \\ Termo de Consentimento Livre e Esclarecido}

\section{Prezado Aluno (a)}

Meu nome é Julio Cesar Rosa. Desenvolvo um estudo sobre mosquitos e problemas ambientais. A finalidade é conhecer o que pensam hoje as pessoas sobre problemas ambientais e mosquitos para contribuir com a elaboração de programas de educação e saúde pública. Para tanto, será realizada entrevista gravada em fita magnética. É uma pesquisa importante para saúde pública.

Estando esclarecido (a) sobre a finalidade do estudo, por favor, assine logo abaixo.

$\mathrm{Eu}$ aluno da série da EE. concordo em participar da entrevista do trabalho citado. Estou ciente que estas informações serão utilizadas somente para pesquișa citada, com a manutenção de absoluto sigilo.

107.

assinatura

Julio Cesar Rosa

Faculdade de Saúde Pública

Universidade de São Paulo

RG: 17480823

cesarjra@usp.br

F: 0XX11 95452248

F: 0XX11 28486868 


\section{Anexo III \\ Termo de Consentimento Livre e Esclarecido}

\section{Prezado Pai (s) ou responsável (is)}

Meu nome é Julio Cesar Rosa. Desenvolvo um estudo sobre mosquitos e problemas ambientais. A finalidade é conhecer o que pensam hoje as pessoas sobre problemas ambientais e mosquitos para contribuir com a elaboração de programas de educação e saúde pública. Para tanto, será realizado entrevista gravada em fita magnética. É uma pesquisa importante para saúde pública.

Estando esclarecido (a) sobre a finalidade do estudo, por favor, assine logo abaixo.

$\mathrm{Eu}$, , autorizo

(nome do pai/mãe ou responsável)

meu filho (a) da série

da E.E. a participar da entrevista do trabalho citado. Estou ciente que estas informaçães serão utilizadas somente para pesquisa citada, com a manutenção de absoluto sigilo.

107.

assinatura

Julio Cesar Rosa

Faculdade de Saúde Pública

Universidade de São Paulo

RG: 17480823

cesarjra@usp.br

F: 0XX11 95452248

F: 0XX11 28486868 


\section{Anexo IV}

Cálculo de percentagem - Pergunta 1 - Como os pernilongos se criam (nascem)? Alunos das escolas Parque Ecológico e Irmã Annete.

\begin{tabular}{c|c|c|c}
\hline Idéias centrais & $\mathrm{n}$ - respostas & $\frac{\mathrm{n}^{\circ} \text { respostas } \times 100}{\mathrm{n} 0 \text { entrrevistados }}$ & $\%$ \\
\hline $\mathrm{A}$ & 57 & $57 \times 100 / 194$ & 29,38 \\
$\mathrm{~B}$ & 60 & $60 \times 100 / 194$ & 30,93 \\
$\mathrm{C}$ & 8 & $8 \times 100 / 194$ & 4,12 \\
$\mathrm{D}$ & 24 & $24 \times 100 / 194$ & 12,37 \\
$\mathrm{E}$ & 30 & $30 \times 100 / 194$ & 15,46 \\
$\mathrm{~F}$ & 58 & $58 \times 100 / 194$ & 29,90 \\
$\mathrm{G}$ & 61 & $61 \times 100 / 194$ & 31,44 \\
$\mathrm{H}$ & 2 & $2 \times 100 / 194$ & 1,03 \\
$\mathrm{I}$ & 1 & $1 \times 100 / 194$ & 0,52 \\
$\mathrm{~J}$ & 7 & $7 \times 100 / 194$ & 3,61 \\
$\mathrm{~K}$ & 1 & $1 \times 100 / 194$ & 0,52 \\
$\mathrm{~L}$ & 1 & $1 \times 100 / 194$ & 0,52 \\
$\mathrm{M}$ & 2 & $2 \times 100 / 194$ & 1,03 \\
$\mathrm{~N}$ & 1 & $1 \times 100 / 194$ & 0,52 \\
\hline
\end{tabular}


Cálculo de percentagem - Pergunta 2. Os pernilongos podem provocar problemas para as pessoas? Caso afirmativo? Quais? - Alunos das escolas Parque Ecológico e Irmã Annete.

\begin{tabular}{c|c|c|c}
\hline Idéias centrais & $\mathrm{n}^{\circ}$ respostas & $\frac{\mathrm{n}^{0} \text { respostas } \times 100}{\mathrm{n}^{0} \text { entrrevistados }}$ & $\%$ \\
\hline $\mathrm{A}$ & 91 & $91 \times 100 / 194$ & 46,91 \\
$\mathrm{~B}$ & 16 & $16 \times 100 / 194$ & 8,25 \\
$\mathrm{C}$ & 56 & $56 \times 100 / 194$ & 28,87 \\
$\mathrm{D}$ & 62 & $62 \times 100 / 194$ & 31,96 \\
$\mathrm{E}$ & 2 & $2 \times 100 / 194$ & 1,03 \\
$\mathrm{~F}$ & 3 & $3 \times 100 / 194$ & 1,55 \\
$\mathrm{G}$ & 2 & $2 \times 100 / 194$ & 1,03 \\
$\mathrm{H}$ & 20 & $20 \times 100 / 194$ & 10,31 \\
$\mathrm{I}$ & 14 & $14 \times 100 / 194$ & 7,22 \\
\hline
\end{tabular}


Cálculo de percentagem - Pergunta 3 - o que pode ser feito para acabar com os pernilongos? - Alunos das escolas Parque Ecológico e Irmã Annete.

\begin{tabular}{c|c|c|c}
\hline Idéias centrais & $\mathrm{n}^{0}$ respostas & $\frac{\mathrm{n}^{-} \text {respostas } \times 100}{\mathrm{n}^{0} \text { entrrevistados }}$ & $\%$ \\
\hline $\mathrm{A}$ & 99 & $99 \times 100 / 194$ & 51,03 \\
$\mathrm{~B}$ & 63 & $63 \times 100 / 194$ & 32,47 \\
$\mathrm{C}$ & 44 & $44 \times 100 / 194$ & 22,68 \\
$\mathrm{D}$ & 19 & $19 \times 100 / 194$ & 9,79 \\
$\mathrm{E}$ & 26 & $26 \times 100 / 194$ & 13,40 \\
$\mathrm{~F}$ & 23 & $23 \times 100 / 194$ & 11,86 \\
$\mathrm{G}$ & 7 & $7 \times 100 / 194$ & 3,61 \\
$\mathrm{H}$ & 6 & $6 \times 100 / 194$ & 3,09 \\
$\mathrm{I}$ & 3 & $3 \times 100 / 194$ & 1,55 \\
$\mathrm{~J}$ & 5 & $5 \times 100 / 194$ & 2,58 \\
$\mathrm{~K}$ & 3 & $3 \times 100 / 194$ & 1,55 \\
\hline
\end{tabular}


Cálculo de percentagem - Pergunta $4 \mathrm{Na}$ sua casa os pernilongos costumam picar as pessoas durante o dia ou durante a noite? - Alunos das escolas Parque Ecológico e Irmã Annete.

\begin{tabular}{c|c|c|c}
\hline Idéias centrais & $\mathrm{n}$ o respostas & $\frac{\mathrm{n}^{\circ} \text { respostas } \times 100}{\mathrm{n}^{\circ} \text { entrrevistados }}$ & $\%$ \\
\hline $\mathrm{A}$ & 166 & $166 \times 100 / 194$ & 85,57 \\
$\mathrm{~B}$ & 18 & $18 \times 100 / 194$ & 9,28 \\
C & 8 & $8 \times 100 / 194$ & 4,12 \\
$\mathrm{D}$ & 2 & $2 \times 100 / 194$ & 1,03 \\
\hline
\end{tabular}


Cálculo de percentagem - Pegunta 5 Você acha que alguns problemas ambientais estão associados à criação de pernilongos? De que maneira? - Alunos das escolas Parque Ecológico e Irmã Annete.

\begin{tabular}{c|c|c|c}
\hline Idéias centrais & $\mathrm{n}^{\circ}$ respostas & $\frac{\mathrm{n}^{\circ} \text { respostas } \times 100}{\mathrm{n} \text { entrrevistados }}$ & $\%$ \\
\hline A & 49 & $49 \times 100 / 194$ & 25,26 \\
B & 84 & $84 \times 100 / 194$ & 43,30 \\
C & 9 & $9 \times 100 / 194$ & 4,64 \\
D & 6 & $6 \times 100 / 194$ & 3,09 \\
E & 37 & $37 \times 100 / 194$ & 19,07 \\
F & 9 & $9 \times 100 / 194$ & 4,64 \\
\hline
\end{tabular}

